University of St. Thomas, Minnesota

UST Research Online

Finance Faculty Publications

Finance

$11-28-2017$

Industry Networks and IPO Waves

Mufaddal H. Baxamusa

University of St Thomas - Saint Paul, baxa0428@stthomas.edu

Abu M. Jalal

Suffolk University, ajalal@suffolk.edu

Follow this and additional works at: https://ir.stthomas.edu/ocbfincpub

Part of the Finance and Financial Management Commons

This Article is brought to you for free and open access by the Finance at UST Research Online. It has been accepted for inclusion in Finance Faculty Publications by an authorized administrator of UST Research Online. For more information, please contact asle4660@stthomas.edu. 


\title{
Industry Networks and IPO Waves ${ }^{1}$
}

By

Mufaddal Baxamusa

and

\author{
Abu Jalal
}

\begin{abstract}
We offer a new perspective on why initial public offerings (IPOs) occur in waves and propose that the customer-supplier relationships among industries help propagate IPO waves. Our empirical tests provide evidence that demand shocks increase the number of IPOs in an industry. The shocks then spread upstream through customer relationships leading to an increase in the number of IPOs in more central and connected industries. These findings contribute to the IPO literature by demonstrating the channel through which IPO waves propagate.
\end{abstract}

Keywords: IPO Waves, Network Centrality, Input-output

JEL Classifications: G10, G34

${ }^{1}$ Mufaddal Baxamusa is at the University of St. Thomas, St. Paul, MN, Phone (651) 962-5845, E-mail: baxa0428@stthomas.edu. Abu Jalal is at Suffolk University, Boston, MA, Phone (617) 570-4898, E-mail ajalal@ suffolk.edu. We thank Raj Aggarwal, Andy (Young Han) Kim, Anand Jha, Felix Meschke, Truong Doung, William Johnson and Karen Simonyan. We also thank seminar participants at the University of St Thomas, City University of New York (Brooklyn), Suffolk University, and the discussant at the Eastern Finance Association's annual meeting for helpful comments. All errors are our own. 


\section{Introduction}

A key stylized fact in corporate finance is that initial public offerings (IPOs) vary over time in a wave-like fashion. The literature has put forward a number of theories to explain this phenomenon (Lerner, 1994; Chemmanur and Fulghieri, 1999). However, these explanations typically lack a clear mechanism through which the IPO waves propagate across industries. This is important since waves are generally not localized to a single industry, but cluster across a set of industries. We fill this gap in the literature by proposing that the supplier and customer linkages provide a path through which IPO waves can propagate.

In fact, the industries within an economy do not function independently. They are linked through a network of buyer-seller contracts. Jones (2011) notes the importance of these relationships by showing that trade between industries in the form of intermediate goods accounts for about half the gross output of those industries. Consequently, the customer-supplier relationships can transmit shocks in one industry to other industries. The larger the number of customer or supplier industries, that is, the more centrally located an industry is in the network, the greater the probability that the industry will experience the effects from the transmission of these shocks through the supply chain.

According to standard production functions, output depends on capital and so, an increase in demand will result in an increase in the need for financing. Initial public offerings are a source of funding for some firms. Therefore, as an industry-wide shock to demand transmits to different industries, a number of firms in those industries might undertake IPOs - resulting in the spread of IPOs within and across industries. Since centrally located industries are more likely to feel the transmission effects of shocks, we hypothesize that these industries are more likely to experience IPO waves. 
To test our hypothesis, we collect data on IPOs from Jay Ritter's website. Similar to Chemmanur and He (2011), we define an IPO wave year as the one in which an industry has more IPOs than the 75th percentile of IPOs as compared to its time series. Next, we construct measures of industry centrality by using the input-output tables that the Bureau of Economic Analysis provides (Acemoglu, Akcigit and Kerr, 2015). These tables identify the flow of trade between the industries. We calculate the inter-industry links using Degree centrality, which counts the number of customers and suppliers of an industry, and Eigenvector centrality, which treats connections to more central industries as being more important than connections to less central industries.

The summary statistics show that the IPO waves only occur in a few industries. These industries tend to be more central to and interconnected in the customer-supplier network. The formal empirical results support our hypotheses. We find that the more central industries in the network are more likely to experience IPO waves. In addition, a number of statistical tests, such as the Bayesian Information Criteria, show that the centrality measures are better at explaining IPO waves than most of the widely used variables in the literature, such as the market-to-book ratio.

Following Bartelsman, Caballero and Lyons (1994), we investigate the effect of the externalities that originate from customer and supplier industries and study which of these relationships helps to create IPO waves. Our estimates show that customer relationships provide a pathway for the transmission of shocks that produce IPO waves. The positive relationship between network centrality and IPO waves is stronger when at least one of the customer industries experiences an IPO wave. We explore the time dimension of the IPO waves as well. 
Our results show that the relationship is concave - which indicates an initial increase in the IPO waves of the upstream industry that is followed by a gradual decrease.

To mitigate the concern that our industry-based centrality measures capture an array of industry effects, we use several empirical strategies. First, we add time-varying measures to our regression models such as an industry's concentration, homogeneity, scope, information asymmetry, and relative share in the economy. These control variables serve an important purpose. The structure of an industry is fluid and a number of confounding factors could possibly drive our results. For example, more central industries might have a higher number of firms and thus be more likely to have an IPO wave. By including these independent variables, we show that the centrality measures matter even after controlling for these alternative explanations. Second, while the variables for industry characteristics control for the observed heterogeneity among the industries, we use industry fixed effects to control for the time-invariant unobserved heterogeneity.

Third, we use a difference-in-difference estimation to further establish the causal relationships. We exploit two natural experiments. Our first experiment uses identifiable deregulatory shocks (Ovtchinnikov, 2010). We find that before deregulation, regulated industries have fewer IPO waves than the control industries. This is consistent with the view that regulations act as entry barriers to the industry. However, after deregulation, the number of IPO waves in these industries is greater than those in the control industries. A reason might be that deregulation sets in motion dynamics that ultimately increase the total demand for these industries. The difference-in-difference estimates provide empirical evidence that supports our hypothesis. In the second experiment, we use an economy-wide demand shock - the 1989 Free Trade Agreement (FTA) between the United States and Canada - to isolate the effects of demand 
changes. The advantage of the FTA is that other macroeconomic shocks or economic policies do not confound it, and the agreement affected a large part of the economy. Between 1989 and 1991, the tariff elimination significantly increased competition among firms in the product market and therefore was a negative demand shock for the firms in the United States (Clausing, 2001). The difference-in-difference estimates indicate that the IPO waves and the number of IPOs decreased in the post-FTA period for industries with higher centrality, which supports the demand-based explanation for IPO waves.

This study contributes to the literature in five ways. First, as far as we know, we are the first to establish a link between industry networks and IPO waves. The literature has used customer-supplier relationships among industries to explain mergers and acquisitions. For example, Ahern and Harford (2014) study the effects of industry networks on merger waves. ${ }^{2}$ However, there are significant differences between merger waves and IPO waves. A merger is an investment decision; while an IPO is a financing decision. ${ }^{3}$ Despite some, albeit small, overlaps (e.g., the merger-motivated IPOs as described in Hovakimian and Hutton 2010), the firms participating in these waves are vastly different in their age, size, capital constraints, and growth opportunities. ${ }^{4}$

\footnotetext{
${ }^{2}$ A number of studies like Fee and Thomas (2004), Kale and Shahrur (2007), Shahrur (2005), Becker and Thomas (2010), and Bhattacharyya and Nain (2011) study the effects of mergers on pricing and market power within industries.

${ }^{3}$ The separation principle of investment and financing policies (Fama and Miller, 1972) proposes that these two decisions need not be related even in the presence of imperfect information and market frictions. Indeed, these waves occur at different stages of the business cycle as documented by Rau and Stouraitis (2011). Thus, we argue that firms undertake IPOs to provide funds for future acquisitions.

${ }^{4}$ For example, firms that undertake mergers tend to be older and more mature while IPOs are typically undertaken by younger, emerging firms.
} 
Our second contribution is the identification of the channel through which IPO waves propagate across industries. Since IPO waves mostly occur in times of stock market booms, the IPO literature tends to link IPO waves to stock market-based measures. While these measures have merit, such explanations cannot account for why some industries experience IPO waves while others do not. By focusing on the centrality of industries, we fill this gap in the literature.

Third, there are studies that explore the effects of various other networks on IPOs. For example, Pichler and Wilhelm (2001), Corwin and Schultz (2005), and Chuluun (2014) study the effects of an underwriter network on IPOs. We uniquely contribute to the literature by exploring the relationship between IPO waves and customer-supplier networks and by identifying these networks as the channel through which IPO waves propagate. We show that the customer relationship is among the most important in determining the likelihood of an industry experiencing IPO waves. This finding means that for financing activities, externalities from customers are likely to have a greater effect than those from suppliers.

Fourth, it is not surprising that there is an industry dynamic in IPO waves. For example, the information spillover theories argue that an IPO by one firm reveals information not only about itself but also about its industry peers that results in more accurate valuations of the firms in that industry (see Alti, 2005). Thus, this reduction in information asymmetry creates a cascade of other similar firms going public. Similarly, we propose that an IPO by a firm discloses information about its customers and suppliers and thus helps propagate IPO waves to those industries. Finally, we show that network centrality is one of the most important variables in explaining IPO waves. Our centrality measures explain more statistical variation than most of the other measures in the literature that are based on the stock market. This study thus complements 
the efforts of Butler, Keefe and Kieschnick (2014) to find the most impactful variables for IPO outcomes.

The rest of the paper is organized as follows. Section 2 presents the framework that develops the hypotheses. Section 3 provides a detailed discussion of our data and method. Section 4 describes the empirical results. Section 5 investigates the transmission of IPO waves. We conclude in section 6.

\section{Literature Review and Hypotheses Development}

\subsection{Industry Networks}

A network is a web of interconnected entities (e.g., people, firms, and industries). These entities form the nodes of the network and interact through their links. For example, a network can consist of scholars as nodes and co-authorship as links. While the application of networks in business topics is well established in the management literature (Powell, Koput, and SmithDoerr, 1996; Tsai, 2001), an emerging literature in finance studies the effect of different networks, for example, venture capitalists (Hochberg, Ljungqvist, and Lu; 2010), CEOs (ElKhatib, Fogel and Jandik, 2015), and industries (Ahern and Harford, 2014), on corporate decisions.

Ahern and Harford (2014), who use industry networks to explain merger waves, argue that the industries within an economic system interact with each other as customers or suppliers of goods and services. In these industry networks, the flow of trade provides the links, while the industries are the nodes. A natural implication of this theory is that one industry can transmit its shocks to another industry through trade flows. Thus, the spread of major corporate activities 
across the linked industries can occur. We expand on this argument by applying it to an IPO wave setting.

If an industry experiences a positive demand shock (e.g., a technology shock or a regulatory shock), it responds by producing more. The production function equates the amount produced to a function of investments in capital and labor. Capital investments can be separated into two different categories: fixed investments that are less elastic to its customer-supplier relationships, for example, investments in fixed assets; and investments in intermediate goods. The increased purchase of intermediate goods passes through the customer-supplier relationships and becomes demand for the upstream industries. ${ }^{5}$ One industry's need for total investments is, therefore, a function of the aggregate demand for the intermediate goods that it produces.

A source of financing for some of the firms in an industry is IPOs. ${ }^{6}$ Thus, an increase in the number of IPOs following an increase in demand in the intermediate goods should occur to meet the funding requirements of the firms. Our key assertion is that a shock creates demand for the goods that a particular industry produces. As a number of other industries are linked to this industry through customer-supplier relationships, these connected industries use financings to build additional capacity to meet the increased demand. Essentially, the demand for intermediate goods in turn transfers the effects of these shocks to the entire system, which results in an IPO wave. Ahern and Harford (2014) use the network centrality measures to represent this exposure.

\footnotetext{
${ }^{5}$ In the production function, investments in intermediate goods and investments in fixed assets can, to some extent, substitute for each other. These investment needs can be positively correlated - that is, an increase in the investments in intermediate goods might require an increase in fixed investments. For example, a firm might need to increase its production capacity or purchase more efficient equipment to handle the increased demand. This type of capital needs can be financed through the IPOs as well, leading to an IPO wave.

${ }^{6}$ A firm can finance its capital needs through retained earnings, debt, and stock issuances. The capital structure literature (e.g., Frank and Goyal, 2009) provides insights into the conditions under which a firm will choose to issue stocks. We will not discuss the conditions under which firms choose to issue equity, since our study is not about capital structure decisions, but rather about the firms that have decided to issue equity for the first time. However, for completeness, we conduct tests in unreported tables and find that our results are stronger for industries with less tangible assets and lower debt capacity.
} 
There is another channel through which IPO waves can propagate across industries. This is related to the information spillover theory of Alti (2005) that proposes that a reduction in valuation uncertainty increases the likelihood of an IPO wave. As a firm goes through the IPO process, information regarding its relationship with its customers and suppliers, including cashflow correlations, contracts, and trade, might be revealed. This, in turn, reduces the valuation uncertainty of the connected firms and incentivizes them to seek opportunities to become public thus fostering the conditions for an inter-industry IPO wave. Consequently, our hypothesis is:

H1 $_{1}$ (IPO Wave): Central industries are more likely to experience IPO waves.

In principle, the direction of a lead-lag relationship, that is, whether the customer or supplier relationships drive these effects, is an empirical question. The economics literature extensively studies the transmission of externalities through the production functions of industries linked by customer-supplier relationships. Bartelsman, Caballero and Lyons (1994) find that customer relationships play an important role in the transmission of externalities when they use time series properties of the data. We build on these studies by arguing that intermediate goods account for about half the output that an industry produces (see Jones, 2011). As a result, if a customer industry experiences a shock, that industry is likely to transmit that shock to the supplier industry through purchases of intermediate goods. The firms undertake IPOs to fund their investment needs because of demand shocks. Therefore, we hypothesize,

$\mathbf{H}_{2}$ (Customer Relations): Customer relationships transmit IPO waves.

\subsection{Alternate Stories for Industry Characteristics}

\subsubsection{Market Imperfections and IPO waves}


The literature on IPO waves has focused largely on stock market imperfections. For example, Ritter (1991), and Loughran, Ritter, and Rydqvist (1994) use the overvaluation of stocks to explain this phenomenon. The key argument is that a large number of IPOs occur when the stock market is booming and hence, the managers are likely exploiting mis-valuations. Consequently, the industries that the market overvalue, as measured by market-to-book ratio, are more likely to undergo IPO waves (for a critique of this literature see Pastor and Veronesi, 2005 and Schultz, 2003). In our empirical tests, we account for these mis-valuations by including a number of control variables such as the market-to-book ratio, stock market returns, stock market risk, profitability, spread of AAA corporate bonds over similar maturity Treasury bonds, and an indicator for hot IPO periods.

\subsubsection{Information Asymmetry and Rational Expectations}

Our hypothesis regarding the effects of industry centrality can co-exist with the information asymmetry, information spillover, and rational expectations hypotheses. Our goal is not to establish industry centrality as the sole factor, but rather one of the most important facilitators of IPO waves.

\section{A) Information Asymmetry and IPO Waves}

A large set of models that attempt to explain IPO waves depend on the inherent information asymmetry between a private firm and its investors. The information asymmetry hypothesis predicts that due to the adverse selection costs associated with IPO issuance, a firm will only go through with an IPO process when the proceeds from the IPO will exceed all of the costs. Thus, IPO waves will occur when information asymmetry is lowest in the market 
(Benninga, Helmantel and Sarig, 2005, Lowry, 2003; He, 2007). As He (2007) shows, the information that investment banks produce allows low quality firms to go public in periods of hot equity markets. This phenomenon increases the likelihood of high quality firms going public in more favorable valuations and thus, creating an IPO wave. So, changes in information asymmetry might explain IPO waves at the industry level. These studies rely on a reduction in stock market frictions to help lower information asymmetry and adverse selection costs.

\section{B) Information Spillover and IPO Waves}

The information spillover theories take advantage of the sequential disclosure of information after a firm goes public. Alti (2005) proposes that because investors cannot know the true value of a private firm, an IPO of a firm within a particular industry discloses more information about the true value of the firms within that industry. This reduces valuation uncertainty for other firms within the industry who are planning their own IPOs. The lowered information cost triggers a number of IPOs within the same industry. Our network story can augment the information spillover theory. Because of the cashflow correlations between customers and suppliers, information spillover can take place among the connected industries. As a firm goes through the IPO process and becomes public, it discloses valuable information about its business model, its cashflows, and the nature of its relationships with its customers and suppliers. An IPO by a firm in one industry, thus, will disclose additional information about the connected firms and their industries even if they are in different industries. In essence, the valuation uncertainty declines and therefore, there is an increase in the likelihood of interindustry IPO waves. 


\section{C) Rational Expectations Models}

In contrast to the market timing hypotheses, Pastor and Veronesi (2005) use neoclassical arguments to explain IPO waves. They propose that declines in expectations about future market returns, not necessarily the ability of the managers to time the market, can explain IPO waves. However, since market mis-valuations can influence variables constructed using market returns, their usage of these variables to empirically test their hypothesis might not sufficiently preclude alternate behavioral explanations.

A number of studies have also argued that IPO waves could occur to provide better value maximization opportunities to the firms, such as identifying potential targets (Zingales, 1995), dispersing ownership (Chemmanur and Fulghieri, 1999), or creating an exit for the founders (Lerner, 1994). Chemmanur and He (2011) study IPO waves under product-market considerations. However, as opposed to our hypotheses, they use a theoretical setting where a firm uses the going public decision as a strategic move to gain product-market share from its private competitors. They show that even after the cost of issuance, a public firm's cost of capital is lower than that of a private firm. Consequently, firms that have sufficient internal capital to fund their optimal investment activities decide to go public with the expectation that its competitors will go public. However, this drive to go public by firms during an IPO wave can turn out to be harmful.

\section{Method and Data}

Following the literature on corporate event waves, our empirical analyses are at the industry level (see Rau and Stouraitis, 2011). 


\subsection{Estimation Models}

We use two main types of regressions models - logit models to estimate the likelihood of the occurrence of IPO waves for central industries and OLS regression models when the dependent variable is the number of IPOs, rather than a dummy variable indicating IPO waves. The estimation models thus take the following form:

$$
y_{i, t}=\alpha+\beta * \text { Centrality Measure } i_{i, t-1}+\gamma X_{i, t-1}+\varepsilon_{i, t}
$$

The dependent variable $y_{i, t}$ represents IPO waves for industry $i$ in year $t$. The Centrality Measure $_{i, t-1}$ comprises industry-specific and time-varying network centrality measures. The set of control variables are computed for industry $i$ in year $t-1$. We add time fixed effects and industry fixed effects to control for heterogeneity. We also use robust standard errors.

\subsection{Customer-Supplier Network}

Our centrality measures for the customer-supplier network use data from the Benchmark Input-Output Use Tables provided by the Bureau of Economic Analysis (BEA). The BEA publishes these tables every five years. For example, we use the 1987 benchmark I-O table's information to compute the centrality measures for the years 1987 to 1991. As the independent variables are lagged by a year in (1), the IPO waves in the years 1988 through 1992 are explained by the 1987 benchmark I-O table. One period's benchmark table is mapped to the previous year's by using the concordance tables provided by the BEA. We implement this algorithm for our entire sample period. 
In essence, the I-O tables measure the interdependencies among industries in the economy. For example, for the industry pair $\mathrm{i}$ and $\mathrm{j}$, the tables provide the value of industry i's output required to produce industry j's total output. The Input-Output tables provide the commodity flow information for 498 industries. The industries are defined using intermediate six-digit I-O industries. While the industry definitions tend to change fairly regularly, the BEA provides concordance tables that map previous classification schemes to current ones as well as the links between I-O industries and SIC codes. Notably, some of these I-O industries do not produce any output and some are not separately identifiable based on SIC codes.

\subsection{IPO Waves}

The data for IPOs are from Jay Ritter's website for the years 1975 to $2011 .^{7}$ He provides information on the firms undergoing an IPO process each year and their SIC industry codes. Since SIC codes have gone through significant revisions over the years, we use the information from BEA to carefully create concordance tables and map them to the I-O industries. Then, we identify the industries that are part of an IPO wave. There is an established literature that uses the $75^{\text {th }}$ percentile of the volume of IPOs for all years for that industry (see Chemannur and He, 2011; Helwege and Liang, 2004; Pastor and Veronesi, 2005). Analogously, we define an IPO wave as occurring when an industry has more IPOs than the 75th percentile of IPOs, compared to its industry time series. Using the $75^{\text {th }}$ percentile reduces the likelihood that the IPO wave variable is affected by random variations in the number of IPOs. Following, Chemannur and $\mathrm{He}$ (2011) we reduce the possibility of misclassifying small number of IPOs as an IPO wave by not classifying any industry-year that has four or fewer IPOs as waves. For robustness purposes, we

\footnotetext{
${ }^{7} \mathrm{http}: / /$ bear.warrington.ufl.edu/ritter/ipodata.htm
} 
also use an alternate definition of IPO waves from the literature that counts the number of IPOs in an industry.

Our final sample consists of I-O industries for which there is at least one IPO wave for our sample period. The non-IPO wave industries excluded from the sample are significantly different from the IPO wave industries in terms of size and profitability. Additionally, the excluded industries tend to be less central with very few linkages to other industries. However, in unreported tables, adding these industries generally increases the statistical significance of the results.

Figure 1 shows that the number of IPO waves and the gross number of IPOs per year are highly correlated. This figure supports our classification of IPO wave industries from the underlying data. For instance, both the maximum number of IPOs and the maximum number of industries with IPO waves occur in 1996. The data underlying Figure 1 is presented in Table 1. Panel A reports the number of IPOs and IPO waves by year. Panel B reports the number of years an I-O industry experienced a wave. There are 127 industries that experienced at least one IPO wave over the sample period of 36 years. This finding means that less than $27 \%$ of the industries experience an IPO wave in our sample period. The implication is that IPO waves are restricted to a select group of industries. Panel $\mathrm{C}$ reports the top five IPO industries. The computer and data processing services industry had the largest number of IPOs over our sample period, followed by retail trade, drugs, wholesale trade, and medical instruments industries.

In Figure 2, we plot the inter-industry customer-supplier relationships. The nodes are the industries while the lines represent the customer-supplier relationships. The arrows show the direction of the flow of goods. For example, if an industry has an arrow pointed toward it, then it is a customer industry. The industry that has the arrow pointed away from it is the supplier 
industry. This graph is drawn for the "hot" IPO period between 1997 and 2000 and only contains industries that experienced IPO waves during the "hot" years. Three observations follow from this graph. First, IPO wave industries rarely exist in isolation, but are generally interconnected with one another. Second, as Panel A of Table 2 shows, IPO waves are concentrated among a few industries. Third, these relationships frequently go in both directions.

\subsection{Centrality Measures}

We use the industry input-output relationships to construct the standard centrality measures. To this end, we designate each industry as a node or an end point in the industry network. If two industries have a customer-supplier relationship, then there will be a connection between the two nodes. However, not all industries are connected to each other. Some are connected to a significant number of other industries, while others are isolated or self-sufficient. Studies have used a number of centrality measures. For brevity we report the results of the two most common (see Hochberg, Ljungquist, and Lu 2010) - Degree and Eigenvector. Our results are robust to the usage of other centrality measures, such as Closeness and Betweenness.

Our first measure Degree is a local measure of centrality and indicates the importance of a particular industry to the whole ecosystem. This measure counts the number of ties a node has, divided by the number of possible connections. The connections measured in Degree could be in both directions (i.e., both as suppliers and as customers). Panel A of Table 2 shows that the IPO wave industries, on average, have higher values of Degree than non-IPO wave industries. We also provide the average centrality for IPO wave and non-IPO wave industries for each calendar year in Figure 3. We observe that in almost all years, the IPO wave industries have a higher average Degree than non-IPO wave industries. 
The second measure of centrality is Eigenvector. The Eigenvector gives greater weight to a node that is connected to other central nodes. In other words, an important industry that is connected to other important industries will have a greater Eigenvector value. Thus, higher Eigenvector values identify leaders in the network. However, since this measure gives greater importance to other high scoring nodes, it might ignore smaller more distant network connections. Panel A of Table 2 shows that the difference between the Eigenvector for average IPO wave industries and that for average non-IPO wave industries is 0.1835 and is statistically significant.

The correlation of the values across the different benchmark I-O tables is high. For example, the correlation between Degree in 1982 and 1992 is 89\%. Similarly, the Eigenvectors have a correlation of $90 \%$. We know that the market share of firms within an industry change significantly over time. Chemmanur and He (2011) find that after an IPO wave the productmarket share of the IPO firms increase sharply while that of the private firms decline. However, the industry information in the I-O tables contains both public and private firms. Hence, the industry connections measured by I-O tables remain fairly stable over time.

Our data on industry characteristics are from CRSP and Compustat. We map the SIC codes to I-O industry codes and compute our variables of interest. To test our hypotheses, we calculate the dependent variable IPOwave. The IPOwave is an indicator variable equal to one that signifies an IPO wave in the I-O industry, and is zero otherwise. The average value of IPOwave, as reported in Panel $\mathrm{C}$ of Table 2, is 0.07 that indicates $7 \%$ of the industry-year observations have an IPO wave. The average number of IPOs, as represented by the variable IPOnum, is 1.91 that indicates on average that there are approximately two IPOs per year per 
industry. This amount might appear low but a large number of industries do not have an IPO in some years.

\subsection{Costs of Capital and Other Control Variables}

In the IPO literature, the direct and indirect costs of capital have played a prominent role in explaining IPO waves. As control variables, in all of our regressions we add FF4F Alpha, the one-year lagged four-factor Fama-French intercept (Fama and Miller, 1972) of the IPO industry; and Sretx, the volatility in the returns one year before the IPO. They capture the pricing errors and return volatility of the firms in an industry (Pastor and Veronesi, 2005). The summary statistics on these variables are reported in Panel B of Table 2. The value of FF4F Alpha is positive and is consistent with those reported in the literature. A number of studies use the market-to-book ratio to measure the mispricing of an equity (Shleifer and Vishny, 2003). So, we add $M B$, the median market-to-book ratio of the industry one year before the IPO, as an independent variable in all of our regression models. We also add Hot, a dummy variable that takes the value of one for the years 1997 to 2000 , to capture the period related to the internet boom that saw an unusually high demand for and high underpricing of IPOs (see Ritter and Welch, 2002). The AAA-10yr is the spread between the AAA-rated corporate bond and the constant maturity ten-year Treasury. This variable is obtained from the St. Louis Federal Reserve Bank (https://research.stlouisfed.org/fred2/). This spread captures the macroeconomic liquidity. During periods of higher macroeconomic liquidity, the cost of capital is lower and the stock market is more likely to boom. It also captures the corporate credit risk environment. A narrowing of the spread implies that the market is factoring in lower risk due possibly to the improving outlook for corporations. 
We use Compustat to construct the other control variables. The Profit is the median profitability of the industry one year before the IPO. The Leverage, calculated as the median leverage of the industry one year before the IPO, reflects the capital structure of the firms in the industry. The Tang reflects the asset composition of the average firm in a particular industry. It is calculated as the median tangibility of assets in the industry one year before the IPO. Investment on capital goods is captured by Capx, which is defined as the median CAPX/AT of the industry one year before the IPO. Further, to capture the asset size of the firms in the industry, we compute Size as the median of the natural logarithm of the total assets of the firms in the industry one year before the IPO. The Mkt-rf is the market return minus the risk-free rate. This variable is computed using data from Kenneth French's website and represents the equity risk premium. The Stock Vol is the average of the standard deviation in the stock returns of all firms in a particular industry. The standard deviations are initially calculated using monthly data. The GDP Growth is the year over year percentage change in the real per capita GDP. Similarly, Invest Growth is the year over year percentage change in real private nonresidential fixed investment. The GDP Growth and Investment Growth variables follow Lowry (2003) and capture the macroeconomic conditions of the country.

We also use proxies for information asymmetry that follow Lowry (2003). The Earn AR Disp is the standard deviation in the abnormal stock returns around earnings announcements (one day prior to the announcement to one day after the announcement) in the last quarter of the fiscal year for the corporation. The Analyst Disp is the average of the standard deviation in the analysts' recommendations on earnings per share. This is also calculated for the recommendations in the last quarter of the fiscal year of the firm. The data are obtained from the IBES database. 
The summary statistics for these variables are presented in Panel C of Table 2. They are consistent with those reported in the literature. In addition to these common control variables, we use other independent variables wherever necessary. For example, we add year dummy variables to capture the effects of business cycles.

\subsection{Industry Characteristics Controls}

To account for industry heterogeneity and to ensure that the coefficient estimates of the centrality measures are not driven by changes in the industry characteristics, we control for the industry's concentration, homogeneity, scope, and relative share in the economy. The variable Herfindahl is the Herfindahl-Hirschman Index that is calculated by using the relative sales of firms within an industry. Higher values indicate higher concentration. It approaches zero when there are a large number of firms of similar size and approaches one when the industry is controlled by a single firm. Essentially, this variable changes as either the number of firms or their relative size changes. Industry Homogeneity measures the extent to which the firms within an industry are statistically similar. We calculate this variable following Parrino (1997) as the partial correlation of the monthly returns of the firms in that industry on an annual basis. The higher the value of this variable, the more homogeneous the industry is. Industry Scope on the other hand takes into account the variations in the types of goods and services an industry produces. It is calculated following Ahern and Harford (2014) where we calculate the percent of all four-digit SIC codes that map to a particular IO industry.

If IPO waves are driven by investment needs, as we argue, then the share of an industry in the economy and the number of firms in that industry should increase following demand shocks. To ensure that our results are not driven by this issue and that the centrality measures 
matter even after controlling for the share of an industry in the economy, we add two controls for the relative size of the industry in the economy - Firms in Ind and Sales Ind. The Firms in Ind is the number of firms in the industry in a particular year divided by the total number of firms for that year. The Sales Ind is the dollar sales of the industry in a year divided by the dollar value of the sales by all companies for that year. ${ }^{8}$ The summary statistics are presented in Panel B of Table 2.

These variables control for the observable heterogeneity among the industries. To account for unobservable heterogeneity, we use the industry fixed effects in our regression models. Additionally, we use two sets of natural experiments where we take advantage of the difference-in-difference method.

\section{Industry Network Centrality and IPO Waves}

We begin our empirical analyses by exploring the link between the centrality measures and the likelihood of the occurrence of IPO waves as stated in our first hypothesis. The regression estimates are presented in Panel A of Table 3. In columns (1) and (2) we use a logit regression model where the dependent variable is IPOWave. We add Degree and Eigenvector one at a time since they are highly correlated with each other. If the centrality of an industry in

\footnotetext{
${ }^{8}$ Ideally, to formulate measures of an industry's share of the overall economy, we would require data on private firms, as these are the ones that can potentially go public. The Census Bureau (https://www.census.gov/data/tables/time-series/econ/susb/susb-historical.html) provides data on the total number of firms in the United States since 1986. However, the individual industry break-downs, that is, the number of firms per industry, are available only since 1997. Incorporating this variable in our regressions will substantially shrink our sample and make it impossible for us to conduct some of the important robustness tests. The Census Bureau does provide the number of establishments (establishments are the different locations from which the firm operates) per industry from 1986 (https://www.census.gov/programs-surveys/cbp/data/datasets.html). However, using the number of establishments can be misleading as a firm is likely to have many establishments. Also, the number of establishments change very regularly because of business dynamism (Bernard, Redding, and Schott, 2010) and so is an inaccurate proxy for the number of firms in an industry. The finance literature, thus, commonly uses the Compustat database of public firms as a proxy for the entire industry consisting of both public and private firms (for a recent example, see Grullon, Larkin, and Michaely, 2016).
} 
the system is indeed important, we expect to observe positive and statistically significant coefficients for the centrality measures. For both centrality measures, we observe positive coefficients and they are statistically significant at the $1 \%$ level. These estimates supports our first hypothesis that central industries are more likely to experience an IPO wave. The coefficients are economically significant as well. A $1 \%$ increase in Degree increases the probability of observing an IPO wave by about $2.1 \%$. Similarly, a $1 \%$ increase in Eigenvector increases the probability of an IPO wave by about $2.5 \%$. Industry centrality therefore plays an important role in IPO waves.

Among the other control variables, capital expenditure is positive and statistically significant. This finding indicates that industries with higher capital expenditure are more likely to have an IPO wave. Additionally, industry scope has a positive and statistically significant coefficient estimate. This finding means that industries that produce a diverse set of outputs are more likely to experience IPO waves.

The dummy variable IPOwave in columns (1) and (2) might not capture the depth of the IPO waves. As such, we construct an alternate definition of IPO waves where we enter the number of IPOs, IPOnum, as the dependent variable. This definition is widely used in the IPO literature (e.g., see Pastor and Veronesi, 2005). The results are in columns (3) and (4). For each of the centrality measures, we observe positive coefficients that are statistically significant at the $1 \%$ level. This finding provides further support for the argument that central industries are more likely to experience an IPO wave.

As a further robustness check, we re-estimate our basic regression models with the Cox proportional hazard model (Cox, 1972). In discrete outcome models, such as logit regressions, the timing of the events, in our case IPO issuance, is not explicitly incorporated. Hazard models 
do that and thus, use the data more efficiently. In our Cox proportional hazard model, we define a private firm going through the IPO process in an IPO wave year as the survival event. The model will thus estimate the probability of a private firm participating in an IPO wave. Therefore, the hazard rate is the instantaneous rate of exit through an IPO for a firm that has not done it yet. The Cox model is semiparametric and does not make any assumption about the nature or shape of the hazard function. More importantly, it takes into account the fact that not all industries must go through an IPO wave - other possibilities exist for these industries.

In columns (5) and (6), the dependent variable is IPOwave. The coefficients support our original conclusions regarding the relationship between industry centrality and the likelihood of IPO wave. All coefficients are positive and statistically significant. Thus, these results support our claim that the industry-customer relationship propagates the positive relationship between industry centrality and the likelihood of an IPO wave.

To ascertain the marginal significance of the various factors in explaining IPO waves, we calculate and present four sets of statistics - odds ratio, z-statistics, Wald Chi, ${ }^{2}$ and Bayesian Information Criteria (BIC). These statistics indicate whether the inclusion of a particular factor improves the empirical model and if so, by how much. Higher values of the odds ratio, zstatistic, and Wald $\mathrm{Chi}^{2}$ mean that a particular explanatory variable has greater influence. But, when choosing a model, the one with the lowest BIC is better. The results are presented in Panel $\mathrm{B}$ of Table 3. We concentrate on the difference between centrality measures (Degree and Eigenvector) and the market based factors (FF4F Alpha, MB, and Hot). Across all four tests, the centrality measures perform better than all of the market factors. Therefore, the centrality measures explain IPO waves as well as, if not better than, a number of the widely used stock market based indicators. 


\subsection{Robustness - The Non-"Hot" Years}

In U.S. economic history, the late 1990s are somewhat exceptional. This period is characterized by a significant expansion of listed firms, especially in the technology sector. For example, the increase in internet usage in the later part of the decade (the "Hot" years were from 1997 to 2000) saw a jump in technology related firms going public. Firms that had customersupplier relationships with these internet-based firms, for example, computer equipment manufacturers, content providers, cable companies, and customer relation management software companies, saw an increase in demand, had large capital needs, grew quickly, and went through the IPO process. Thus, the observations from this period might have an outsized effect on our results.

Therefore, we examine whether the relationship between industry centrality and IPO waves holds outside of this period. Two possible options exists for this examination: add an interaction term for the "Hot" years and the centrality measures in the regressions; or drop the observations from the "Hot" years from 1997 to 2000 and re-estimate the regression models. We have replicated the results in both ways. For brevity, we only report the results from dropping the "Hot" years in Table 4. It is possible that the relationship between IPOs and a number of these independent variables might be different during the "Hot" years and so, reporting the results without the "Hot" years might reflect the underlying relationships more accurately. We find that our results hold for the strictly non-"Hot" years. Compared to Panel A of Table 3, the coefficients for Degree and Eigenvector in Table 4 are slightly smaller, but they remain positive and statistically significant in all cases. Thus, the effects of centrality on IPO waves persist outside of the internet period. 


\subsection{Positive Demand Shock - Deregulated Industries}

So far we have investigated the relationship between IPO waves and the industry's centrality measures. To generate our hypothesis, we argue that these customer-supplier relationships transmit shocks. It follows that we should explore these shocks to get a better understanding of the process. We concentrate on deregulatory shocks since deregulation is a political process and thus, is relatively exogenous to the industry. In general, there are two major theories that explain the effect of deregulation - public interest and University of Chicago theories. As argued in Noll (1989), the public interest theory states that deregulation should improve efficiencies that benefit the consumers as industries are deregulated to benefit the public. The Chicago theory was developed by Peltzman (1976). It argues that deregulation should increase social welfare because the deadweight costs that are associated with the rentseeking of certain groups that benefit from regulation should dissipate under competition. Both of these theories suggest that increased competition due to deregulation should remove the inefficient firms and the inefficiencies from the surviving firms - ultimately benefiting the consumers. As the consumers' benefits increase, the industry's total demand should also increase.

We obtain a list of deregulatory shocks from Ovtchinnikov (2010). There are a total of 25 shocks. When industries experience multiple shocks, the second shock occurs after at least five years the first shock. We choose a difference-in-difference estimation since it has the advantage of removing unobserved industry fixed effects and is largely free from endogeneity concerns.

To conduct the difference-in-difference estimation, we construct two sets of treated and control groups - one based on Degree and the other on Eigenvector. For the first set, the treated 
group consists of industries that have experienced shocks and have a Degree with a value larger than the $75^{\text {th }}$ percentile. The control group also experiences shocks and is similar to the treated group in size, year, and profitability. Essentially, the treated and control groups are different in their industry Degree centralities. We create a dummy variable HighDegree that takes the value of one if the industry belongs in the treated group and zero if it belongs in the control group. Similarly, for the second set, we repeat the previous process, except instead of Degree, we take the Eigenvector values. We generate another dummy variable HighEigen that takes the value of one if the industry belongs in this treated group and zero if it belongs in this control group. For the difference-in-difference estimation, we use the industry data for five years before and five years after the industry shocks.

Panel A of Table 5 presents the summary statistics of these treated and control groups. Before deregulation, the treated groups have statistically fewer IPOs and IPO waves than the control groups. For instance, $2.1 \%$ of the control industries experience an IPO wave while only $1.2 \%$ of the treated industries experience an IPO wave. After deregulation, the number of IPOs and IPO waves of both the control and treated groups increase with the treated group having a larger increase. This increase supports the view that regulations act as entry barrier to an industry. Deregulations set in motion industry dynamics that make it attractive for firms to enter. Importantly, after the deregulatory shocks, the relationship reverses and the treated groups have more IPOs and IPO waves. The post-deregulation difference between the treated and control groups is economically significant as $4.5 \%$ more treated industries undergo an IPO wave than the industries from the control group. Column (7) reports that the differences between column (6) and (3) are statistically significant in every row of the table. 
The indicator variable Shock takes the value of one if the observations are from the year after the industry shock and zero otherwise. Our final sample shows that the calendar years of some of the control observations do not coincide with those of the treated observations. This is mainly because of the fact that industry shocks are spread out over many years. This spread could create a situation where the control group might not be able to remove the time trends. Roberts and Whited (2012) suggest a method to check for such a bias through a paired t-test of the growth rates of the key dependent variables in the control group and the treated group for the pre-shock years. In unreported results, we find that the growth rates of the number of IPOs in the pre-shock years are statistically insignificant between the two groups. This means that the trends are similar for the treated and control groups in the pre-shock years. For robustness, we adopt another way to control for time trends by including the year dummies as independent variables. We do so in all regressions.

Panel B of Table 5 reports the regression results. The dependent variables are IPOWave in columns (1) and (2) and IPOnum in columns (3) and (4). The coefficients for the interaction term of HighDegree and Shock are positive and statistically significant in all of the regression estimates. This suggests that highly connected industries are more likely to experience an IPO wave and have a higher number of IPOs following an industry deregulatory shock. These results from the difference-in-difference estimation support our first hypothesis.

\subsection{Downstream Shocks and Upstream IPO Waves}

We next use the deregulatory shocks and the difference-in-difference method to explore how the shocks propagate through the industry network. Specifically, we study whether the shocks travel upstream from downstream industries or vice versa. To conduct this analysis for 
each industry, we create an indicator variable IPOWavel that takes the value of one if any of its upstream industries experience an IPO wave. Similarly, IPOnuml counts the number of IPOs upstream industries experience. We replicate the regression equations presented in Table 5 with these two newly defined variables. We find that the interaction terms HighDegree * Shock and HighEigen * Shock are both positive and statistically significant in all cases. Furthermore, the $\mathrm{Chi}^{2} /$ Adjusted $\mathrm{R}^{2}$ are higher for the estimates presented in Table 6 than those in Table 5. These regression estimates provide evidence that downstream demand shocks lead to IPO waves in upstream industries. This finding supports our second hypothesis that if a customer industry experiences a shock, it is likely to be transmitted to the supplier industry through a shift in demand for intermediate goods.

For completeness, we also perform a similar analysis to study whether shocks to upstream industries lead to IPO waves in downstream industries. We find that the interaction terms HighDegree * Shock and HighEigen * Shock are statistically insignificant in all instances. For the sake of brevity, we do not present these estimates here.

\subsection{Negative Demand Shock -- Free Trade Agreement (FTA) of 1989}

If, as we argue, positive demand shocks result in subsequent IPO waves, then does a negative demand shock result in a decrease in IPO waves? We use a natural experiment that involves a free trade agreement (FTA), which turned out to be a negative demand shock for U.S. firms, and explore whether it depressed IPO waves in the more central industries. In the FTA agreement that Canada and the United States implemented in 1989, both countries agreed to eliminate tariffs. This agreement was important as the Canada-United States trade relationship was the largest in the world at that time and accounted for $20 \%$ of the imports into the United 
States. Clausing (2001) credits the FTA with substantially increasing Canadian exports into the United States.

Tariff elimination generally reduces the price of goods for the consumers and so, is welfare enhancing. However, it might hurt the industries that the tariffs protected. The literature finds that tariff reduction leads to plant shutdowns (Trefler, 2004), lower profit margins (Krishna and Mitra, 1998), and higher unemployment (Beaulieu, 2000). As Canada also agreed to eliminate tariffs, the benefits of the agreement should also flow to the U.S. firms that are in a position to export to Canada. However, Bernard and Jensen (2004) find that only a select set of U.S. firms export to Canada because of substantial sunk costs, and these firms tend to be large. Therefore, the implementation of the FTA is a negative demand shock because of increased product-market competition (Guadalupe and Wulf, 2010).

The FTA of 1989 has several advantages (see Trefler (2004) for an in-depth discussion). First, the adoption of the FTA was unexpected and so, was not accompanied by any confounding macroeconomic shocks. When the initial details of the FTA were released in 1987, the reaction from the Canadian public was negative. The opposition party would not allow the passage of the bill through the parliament and thus, the approval of the FTA was deferred until after the general elections in late 1988. In pre-election polling, the opposition party had an advantage. However, the incumbent government was able to win a closely fought election in which one of the key issues was the FTA.

Second, this negative demand shock for the U.S. firms was accompanied by a rising stock market. A large part of the tariff eliminations took place between 1989 and 1991, while the S\&P 500 stock index rose almost $50 \%$ from 277.72 to 417.03 . Moreover, the stock market experienced the crash of 1987 about 15 months before the implementation of the FTA. 
Therefore, for the purpose of our study, this timing allows us to isolate the effects of the demand shock from those of the stock market returns.

To formulate the treated group, we select all industries that have a Degree with a value larger than the $75^{\text {th }}$ percentile. We use all industries because the FTA was an economy-wide shock (Guadalupe and Wulf, 2009; Clausing, 2001). It removed tariffs on all industries and not just some targeted industries. We then select the control group to be industries that are similar to the treated group in size, year, and profitability. We create a dummy variable HighDegreel that takes the value of one if the industry belongs in the treated group and zero if it belongs in the control group. We repeat the same process with Eigenvector and generate the dummy variable HighEigen1. Next we create another indicator variable called Post-FTA. It takes the value of one if the observations are from three years after the FTA was implemented, and zero for the ones from three years before.

Panel A of Table 7 presents the summary statistics of these treated and control groups. Before the FTA, column (3) shows that the treated and control groups were not statistically different. After the implementation of the FTA, the IPOs and the IPO waves were lower for the high centrality group. The relationship is exactly the opposite of what we observed in Panel A of Table 5 that describes the effects of positive demand shocks due to deregulation.

Panel B of Table 7 shows the results of regressing IPOWave and IPOnum on Post-FTA and its interaction with HighDegreel and HighEigen1. Columns (1) and (2) show that the coefficients for the interaction terms HighDegree ${ }^{*}$ Post-FTA and HighEigenl * Post-FTA are both negative and statistically significant. This result indicates that during the three years after 1989, there was a decline in IPO waves as compared to the three years preceding 1989 for highly central industries. Similarly, columns (3) and (4) report the estimates of the interaction terms of 
Post-FTA and centrality measures using IPOnum as the dependent variable. The coefficients for the interaction terms HighDegree $1 *$ Post-FTA and HighEigen $1 *$ Post-FTA are also negative and statistically significant. This result provides evidence that there were fewer IPOs in the three years following the FTA as compared to the three years before for the highly central industries. These results support our argument that the central industries are more likely to be affected by an economy-wide demand shock, whether it is positive or negative.

However, due to greater overall competition in the product market following the FTA, the prices of intermediate goods might have decreased. If this decrease was the case, we should see a greater occurrence of IPO waves (i.e., positive coefficient estimates for the interaction terms between Post-FTA and the centrality measures). However, we find the opposite results.

\section{Customer Relationships and Industry Centrality}

\subsection{Customer or Supplier with an IPO Wave}

We now turn to our second hypothesis on understanding the mechanism that propagates IPO waves across industry networks. We produce four sets of regression outputs in four different panels in Table 8. In Panel A of Table 8, we explore whether an industry whose customers are experiencing IPO waves undergoes an IPO wave. In Panel B, we repeat this analysis for the industry whose suppliers are experiencing IPO waves. In Panel C, we only consider the industries whose customers go through IPO waves. Then, we split the sample into high and low centrality groups to understand which type of industries is most affected. In Panel D, we repeat this analysis for industries whose suppliers go through IPO waves. For brevity, we only present the results for Degree. 
In the first two columns of Panel A, the dependent variable is IPOwave; and in the last two, it is IPOnum. Columns (1) and (3) have the observations for industries whose customers experience IPO waves, while columns (2) and (4) have those whose customers do not. The coefficients for Degree are statistically significant and positive for industries whose customers go through IPO waves. On the other hand, the coefficients are statistically insignificant for industries whose customers do not go through an IPO wave. The results indicate that the likelihood of an industry undergoing an IPO wave increases with centrality if at least one of its customers experiences an IPO wave. No such statistically significant relationship exists for industries without a customer undergoing an IPO wave.

Similar to the first panel, in the first two columns of Panel B, the dependent variable is IPOwave; and in the last two, it is IPOnum. Columns (1) and (3) have the observations for industries with at least one supplier that experiences an IPO wave, while columns (2) and (4) have those that do not. The coefficients for Degree are statistically significant and positive in all cases, regardless of whether the suppliers go through IPO waves or not. The coefficients in columns (1) and (2) are very similar as well. We conduct a Wald test to compare the coefficients for Degree and find that the $\mathrm{Chi}^{2}$ value is 0.82 , which is statistically insignificant at the $10 \% \mathrm{p}$ value level. Similarly, the coefficients for Degree in columns (3) and (4) are statistically similar $\left(\mathrm{Chi}^{2}=1.17, \mathrm{p}\right.$-value $\left.>10 \%\right)$. Therefore, there does not appear to be any statistically significant difference in the relationship between an IPO wave and network centrality if we sort the industries based on whether their suppliers are going through an IPO wave or not. We next consider only industries whose customers experience IPO waves. We split the sample in half based on the median value of Degree. Columns (1) and (3) of Panel C have the industries whose Degree is higher than the median, while columns (2) and (4) have those whose Degree is lower 
than the median. As before, in the first two columns, the dependent variable is IPOwave; and in the last two, it is IPOnum. The coefficients for Degree are statistically significant and positive for industries whose centralities are higher than the median. On the other hand, the coefficients are statistically insignificant for industries whose centralities are lower than the median. These coefficients provide evidence that the positive relationship between IPO waves and centrality is mainly present among the more central industries.

Further, for the sake of completeness, we take only industries whose suppliers experience IPO waves. We split the sample in half, based on the median value of Degree. As in the previous panel, columns (1) and (3) of Panel D have the industries whose Degree centralities are higher than the median, while columns (2) and (4) have those whose centralities are lower than the median. Similarly, in the first two columns of Panel C, the dependent variable is IPOwave; and in the last two, it is IPOnum. The coefficients for Degree are statistically insignificant in the first two columns. Therefore, there does not appear to be any difference among the industries based on this sorting scheme. However, when it comes to IPOnum as the dependent variable, the relationship between IPOnum and Degree is positive but statistically insignificant for more central industries, but negative and statistically significant for less central industries. While the results are somewhat mixed in this case, we can claim that industries whose suppliers are experiencing IPO waves are no more likely to experience an IPO wave than those industries that are not.

In summary, the four sets of tests presented here provide empirical evidence on how industry centrality influences the ecosystem. The customer-supplier relationship appears to be the channel that spreads an IPO wave from one industry to others. 


\subsection{Intertemporal Characteristics of IPO Waves}

In this study, we propose that IPO waves start among industries following a shock and then the customer-supplier relationships propagate these waves upstream. There is an important time dimension to this proposition. We use Chemmanur and $\mathrm{He}$ (2011) to explore this dimension. We build on the results in Table 8 that show that IPO waves start with a downstream industry experiencing an IPO wave and then transmit to more central upstream industries. Therefore, we only take those industries whose customer industries experience an IPO wave and split them into two groups based on Degree centrality. Next, we construct a new variable Time that counts the number of years since an IPO wave was experienced by the customer industry. Additionally, the relationship between IPO waves and Time should be nonlinear and concave we should observe an increase in IPOs in the upstream industries that should eventually die down. If we find a linear or a convex relationship between IPO waves and Time, there should be continuous and permanent IPO waves. To capture any nonlinearity, we add both the linear variable Time and the quadratic variable Time $^{2}$ as independent variables. A statistically significant and positive coefficient for Time and a statistically significant and negative coefficient for Time ${ }^{2}$ should indicate a concave relationship. This is exactly what we find for the group of more central industries in the estimates presented in Table 9. Both coefficient estimates for Time and Time ${ }^{2}$ are statistically insignificant for the group of industries that are less central. Our results show that the propagation of IPO waves has two intertemporal characteristics - first, the shocks travel to upstream industries after a shock to the downstream industries and second, the relationship is concave in nature - which indicates an initial increase in the IPO waves, followed by a decline. 


\section{Conclusion}

In this paper, we propose a new explanation for IPO waves that is rooted in real economics: customer-supplier relationships. Prior literature observes that industries within an economy cannot function in isolation. They are interconnected through a complex set of ties. The customer-supplier relationship is one such connection. The demand from one industry can transmit to another through these interdependencies. The literature also demonstrates that IPOs occur in a wave-like fashion. Because IPO waves are likely to create a significant ripple in the industries undergoing these events, other industries connected to these industries are also likely to feel the effect of these events.

To develop a better understanding of the relationship between industry networks and IPO waves, we construct a number of industry centrality measures and conduct formal regression analyses. We find that more central industries are more likely to experience an IPO wave. Next we explore the channel through which these IPO waves propagate through the economic system - specifically, we consider the customer-supplier relationships. We find that the positive relationship between network centrality and IPO waves is stronger for industries that have at least one of its customers experiencing an IPO wave.

We perform detailed analyses on the consequences of industry networks on the propagation of IPO waves. Our results show that the long debated questions in the literature like underpricing, age of the firm at IPO, offer price revisions, and post-IPO performance can also be studied by using the customer-supplier relationships. We leave these questions for future research. 


\section{References}

Acemoglu, D., U. Akcigit, and W. Kerr, 2015, Networks and the macroeconomy: An empirical exploration, NBER Working Paper No. 21344.

Ahern, K. and J. Harford, 2014, The importance of industry links in merger waves, Journal of Finance 69, pp. 527-576.

Alti, A., 2005, IPO Market Timing, The Review of Financial Studies 18(3), pp. 1105-38.

Bartelsman, E.J., Caballero, R.J. and Lyons, R.K., 1994. Customer-and supplier-driven externalities. The American Economic Review 84(4), pp.1075-1084.

Beaulieu, E., 2000, The Canada-U.S. Free Trade Agreement and Labour Market Adjustment in Canada, Canadian Journal of Economics, 33 (2), pp. 540-63.

Becker, M. and S. Thomas, 2010, The spillover effects of changes in industry concentration, Working Paper, University of Pittsburgh.

Benninga, S., Helmantel, M., and O. Sarig, 2005, The timing of initial public offerings, The Journal of Finacial Economics, 75(1), 115-132.

Bernard, A., and J. Jensen, 2004, Why some firms export. Review of Economics and Statistics 86.2 , pp. 561-569.

Bhattacharyya, S. and A. Nain, 2011, Horizontal acquisitions and buying power: A product market analysis, Journal of Financial Economics 99, 97-115.

Bernard, A.B., Redding, S.J. and Schott, P.K., 2010. Multiple-product firms and product switching, The American Economic Review 100(1), 70-97.

Butler, A., Keefe, M. and R. Kieschnick, 2014, Robust determinants of IPO underpricing and their implications for IPO research, Journal of Corporate Finance 27, 367-83.

Chemmanur, T. and P. Fulghieri, 1999, A theory of the going-public decision, Review of Financial Studies 12, 249-279. 
Chemmanur, T. and J. He, 2011, IPO waves, product market competition, and the going public decision: Theory and evidence, Journal of Financial Economics, 101(1), 382-412.

Chuluun, T., 2014, The role of underwriter peer networks in IPOs, Working paper, Loyola University Maryland.

Clausing, K. A. 2001. "Trade Creation and Trade Diversion in the Canada-United States Free Trade Agreement," The Canadian Journal of Economics, 34(3): 677-96.

Corwin, S. and P. Schultz, 2005, The role of IPO underwriting syndicates: Pricing, information production, and underwriter competition, Journal of Finance 60, 443-486.

Cox, D., 1972, Regression models and life tables, Journal of Royal Statistical Society 34, 187220.

El-Khatib, R., Fogel, K. and Jandik, T., 2015. CEO network centrality and merger performance. Journal of Financial Economics, 116(2), pp.349-382.

Fama, E. and M. Miller, 1972, The theory of Finance, $1^{\text {st }}$ Edition, New York: Holt Rinehart \& Winston.

Fee, C. and S. Thomas, 2004, Sources of gains in horizontal mergers: Evidence from customer, supplier, and rival firms, Journal of Financial Economics 74, 423-460.

Frank, M. and V. Goyal, 2009, Capital structure decisions which factors are reliably important? Financial Management, Vol. 38, Issue 1, pp. 1-37.

Grullon, G., Larkin, Y., and R. Michaely, 2016. Are US Industries Becoming More Concentrated? SSRN Working Paper.

Guadalupe, M. and J. Wulf, 2010, The flattening firm and product market competition: The effect of trade liberalization on corporate hierarchies. American Economic Journal: Applied Economics 2(4), pp. 105-127. 
He, P., 2007, A Theory of IPO Waves, Review of Financial Studies, 20(4), 983-1020.

Helwege, J. and Liang, N., 2004, Initial public offerings in hot and cold markets, Journal of financial and Quantitative Analysis 39(3), pp. 541-569.

Hochberg, Y., A. Ljungqvist, and Y. Lu, 2010, Networking as a barrier to entry and the competitive supply of venture capital, The Journal of Finance 65(3), pp. 829-59.

Hovakimian, A. and I. Hutton, 2010, Meger-motivated IPOs, Financial Management 39(4), 1547-1573.

Jones, C, 2011, Intermediate goods and the weak links in the theory of economic development, Macroeconomics, Vol. 3, No. 2, pp. 1-28.

Kale, J., and H. Shahrur, 2007, Corporate capital structure and the characteristics of suppliers and customers, Journal of Financial Economics, 83, 321-365.

Krishna, P., and D. Mitra, 1998, Trade Liberalization, Market Discipline and Productivity Growth: New Evidence from India, Journal of Development Economics, 56 (2), pp. 447462.

Lerner, J., 1994, The syndication of venture capital investments, Financial Management 23(3), $16-27$.

Loughran, T., Ritter, J., and K. Rydqvist, 1994, Initial public offerings: International insights, Pacific-Basin Finance Journal 2, 165-199.

Lowry, M., 2003, Why does IPO Volume Fluctuate So Much?, Journal of Financial Economics 67 (1), pp. 3-40.

Noll, R.G., 1989, Economic perspectives on the politics of regulation. Handbook of industrial organization 2, pp.1253-1287. 
Ovtchinnikov, A.V., 2010, Capital structure decisions: Evidence from deregulated industries. Journal of Financial Economics, 95(2), pp.249-274.

Parrino, R., 1997. CEO turnover and outside succession a cross-sectional analysis. Journal of Financial Economics, 46(2), pp.165-197.

Pastor, L. and P. Veronesi, 2005, Rational IPO Waves, Journal of Finance 60, 1713-1757.

Peltzman, S., 1976, Toward a more general theory of regulation. The Journal of Law and Economics, 19(2), pp.211-240.

Pichler, P. and W. Wilhelm, 2001, A theory of the syndicate: Form follows function, Journal of Finance 56, 2237-2264.

Powell, W., K. Koput, and L. Smith-Doerr, 1996, Interorganizational collaboration and the locus of innovation: Networks of learning in biotechnology, Administrative Science Quarterly, pp. 116-145.

Rau, P. and A. Stouraitis, 2011, Patterns in the timing of corporate event waves, Journal of Financial and Quantitative Analysis 46(1), 209-246.

Ritter, J., 1991, The long-run performance of initial public offerings, Journal of Finance 46, 327.

Ritter, J. and I. Welch, 2002, A review of IPO activity, pricing, and allocations, Journal of Finance 57, 1795-1828.

Roberts, M., and T. Whited, 2012, Endogeniety in Empirical Corporate Finance, Simon School Working Paper No. FR. 11-29.

Schultz, 2003, Pseudo market timing and the long-run underperformance of IPOs. Journal of Finance, 57, 483-511. 
Shahrur, H., 2005, Industry structure and horizontal takeovers: Analysis of wealth effects on rivals, suppliers, and corporate customers, Journal of Financial Economics 76, 61-98.

Shleifer, A., and R. Vishny, 2003, Stock market driven acquisitions, Journal of Financial Economics, Vol. 70, Issue 3, pp. 295-311.

Trefler, D., 2004, The Long and Short of the Canada-U.S. Free trade Agreement, The American Economic Review 94 (4), pp. 870-895.

Tsai, W. 2001, "Knowledge Transfer in Intra-organizational Networks: Effects of Network Position and Absorptive Capacity on Business Unit Innovation and Performance”, Academy of Management Journal, Vol. 44, No. 5, pp. 996-1004.

Zingales, L., 1995, Insider ownership and the decision to go public, Review of Economic Studies $62,425-448$. 
Figure 1: IPO Waves in the U.S.

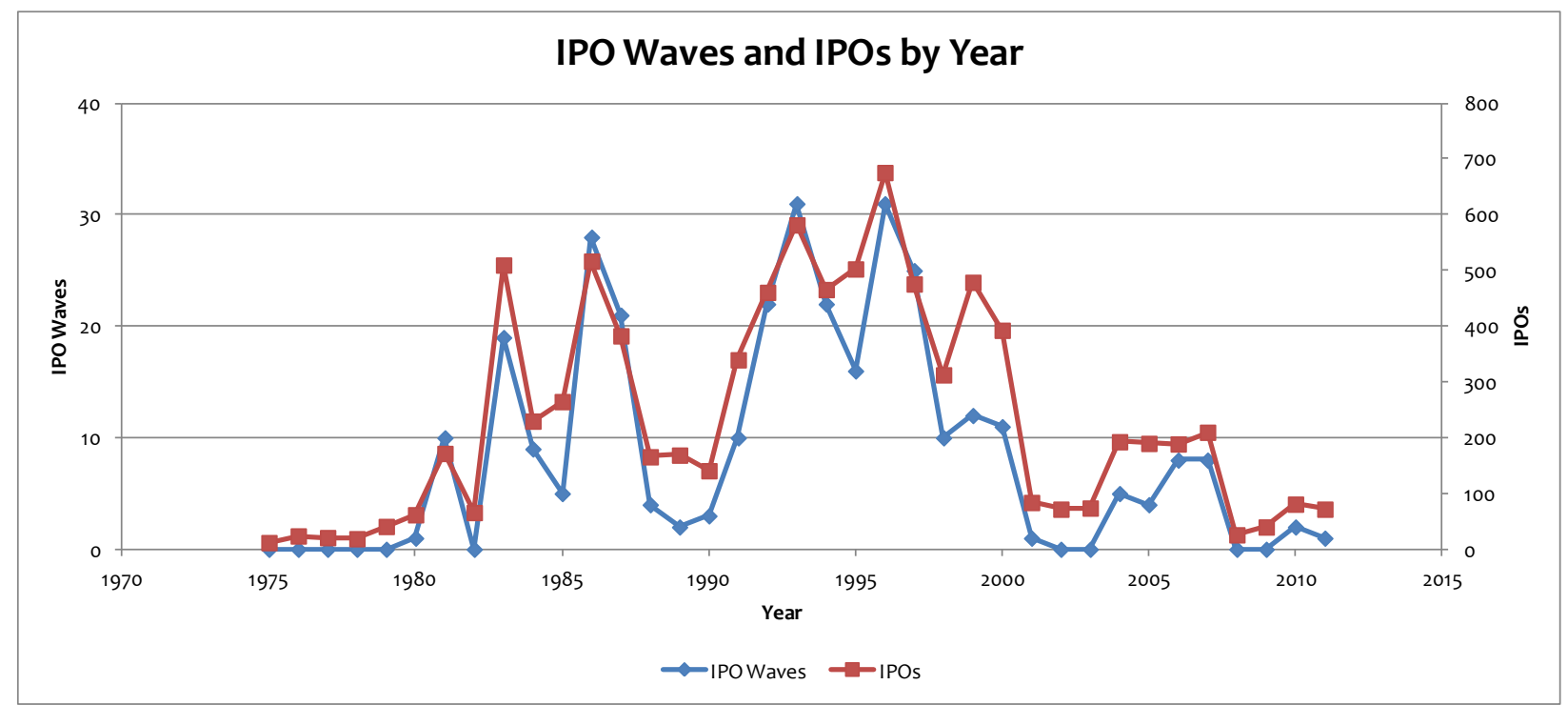

This graph compares the number of industries experiencing IPO waves (left vertical axis) to the total number of IPOs issued per year (right vertical axis) by year. We define the industry by its six-digit I-O categories. 
Figure 2: Customer-Supplier Connections among IPO Wave Industries during Hot IPO Years (1997 to 2000)
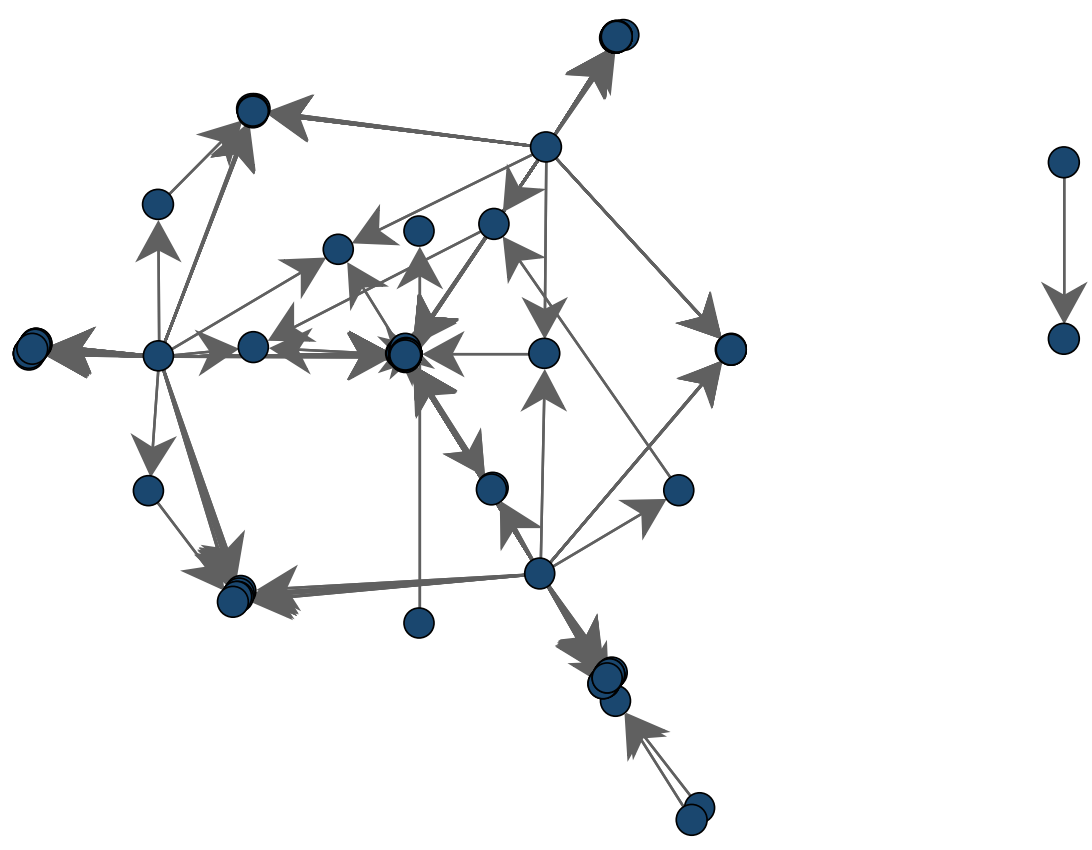

This plot shows the customer-supplier connections between industries undergoing IPO waves. The sample period is 1997 to 2000 (i.e., the hot years). The arrows show the direction of the flow of intermediate goods. So, an arrow toward an industry means that it is a customer, while the arrow pointing away from the industry means that it is a supplier. 


\section{Figure 3: Network Centrality of Industries}

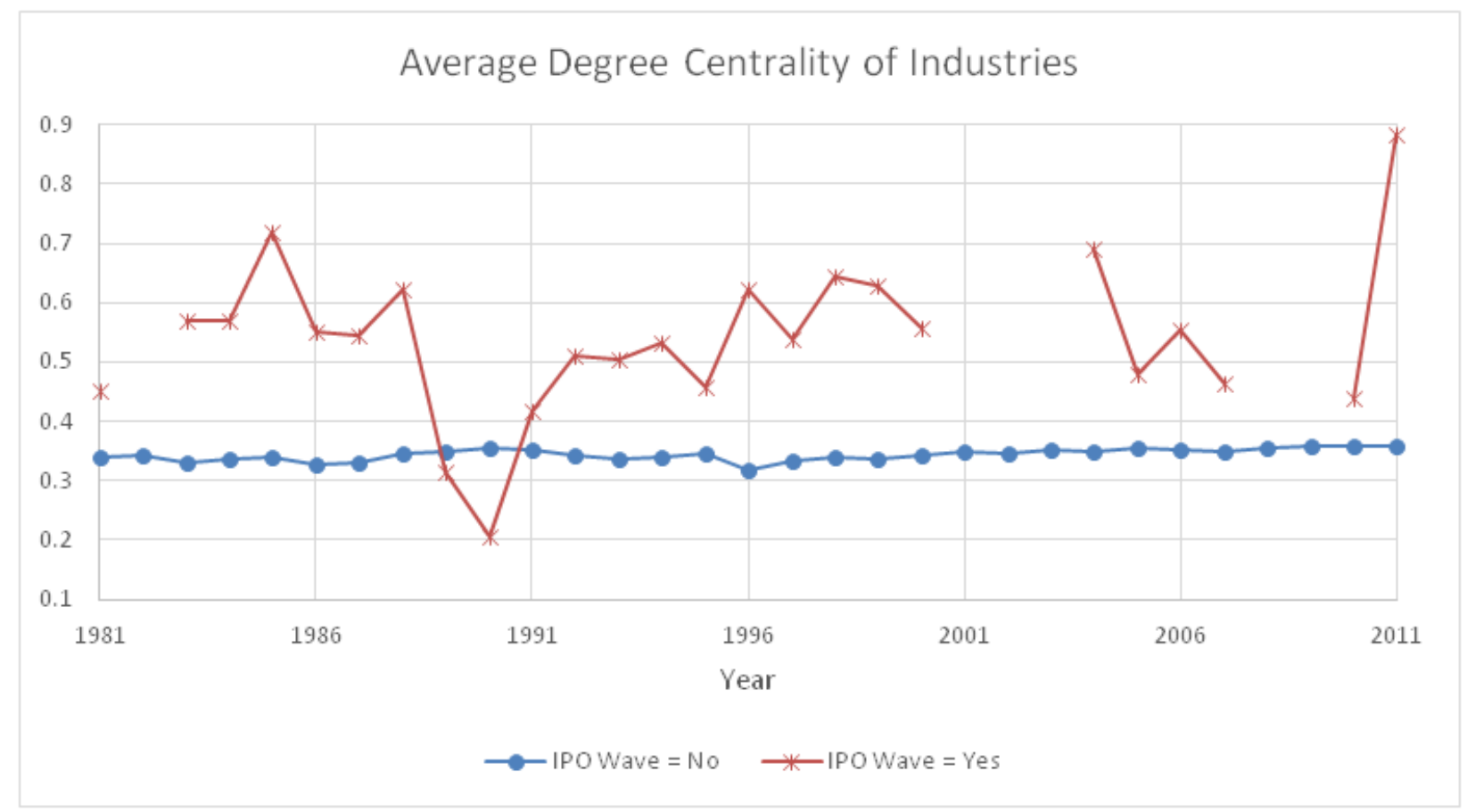

This graph plots the average centrality measure (Degree) of industries experiencing IPOs by year. Missing values indicate no IPO wave for that year. We define industry by its six-digit I-O categories. 
Table 1: Panel A) Annual Number of IPOs and IPO Waves

\begin{tabular}{|c|c|c|}
\hline Year & $\begin{array}{c}\text { Number of IPOs } \\
\text { (1) } \\
\end{array}$ & $\begin{array}{c}\text { Number of Industries } \\
\text { with IPO Waves } \\
(2) \\
\end{array}$ \\
\hline 1975 & 12 & 0 \\
\hline 1976 & 24 & 0 \\
\hline 1977 & 21 & 0 \\
\hline 1978 & 19 & 0 \\
\hline 1979 & 41 & 0 \\
\hline 1980 & 62 & 1 \\
\hline 1981 & 172 & 10 \\
\hline 1982 & 66 & 0 \\
\hline 1983 & 510 & 19 \\
\hline 1984 & 230 & 9 \\
\hline 1985 & 265 & 5 \\
\hline 1986 & 517 & 28 \\
\hline 1987 & 383 & 21 \\
\hline 1988 & 166 & 4 \\
\hline 1989 & 169 & 2 \\
\hline 1990 & 141 & 3 \\
\hline 1991 & 340 & 10 \\
\hline 1992 & 461 & 22 \\
\hline 1993 & 582 & 31 \\
\hline 1994 & 466 & 22 \\
\hline 1995 & 503 & 16 \\
\hline 1996 & 676 & 31 \\
\hline 1997 & 476 & 25 \\
\hline 1998 & 313 & 10 \\
\hline 1999 & 479 & 12 \\
\hline 2000 & 393 & 11 \\
\hline 2001 & 84 & 1 \\
\hline 2002 & 72 & 0 \\
\hline 2003 & 74 & 0 \\
\hline 2004 & 193 & 5 \\
\hline 2005 & 190 & 4 \\
\hline 2006 & 189 & 8 \\
\hline 2007 & 210 & 8 \\
\hline 2008 & 26 & 0 \\
\hline 2009 & 40 & 0 \\
\hline 2010 & 81 & 2 \\
\hline 2011 & 72 & 1 \\
\hline Total & 8718 & 321 \\
\hline
\end{tabular}


This panel shows the number of IPOs and IPO waves by year.

Panel B) IO Industries and Number of Years with IPO
\begin{tabular}{cc}
\hline \multicolumn{1}{c}{ Years with Waves } & Number of IO Industries \\
$(1)$ & $(2)$ \\
\hline 1 & 43 \\
2 & 34 \\
3 & 26 \\
4 & 8 \\
5 & 5 \\
6 & 6 \\
7 & 2 \\
8 & 2 \\
9 & 1 \\
Total & 127 \\
\hline
\end{tabular}

This panel categorizes the number of IO industries by the number of IPO waves they have experienced during the sample period.

\section{Panel C) Top 5 IPO Industries in I-O Classification}

\begin{tabular}{clc}
\hline $\begin{array}{c}\text { I-O Industry } \\
(1)\end{array}$ & \multicolumn{1}{c}{$\begin{array}{c}\text { Industry Description } \\
(2)\end{array}$} & $\begin{array}{c}\text { Number of IPOs } \\
(3)\end{array}$ \\
\hline 730104 & Computer and data processing services & 1148 \\
690200 & Retail trade, except eating and drinking & 501 \\
290100 & Drugs & 408 \\
690100 & Wholesale trade & 406 \\
620400 & Surgical and medical instruments and apparatus & 226 \\
\hline
\end{tabular}

This panel counts the number of IPOs by six-digit I-O industry codes between the period 1975 and 2011. 
Table 2) Summary Statistics

Panel A) Average Alternately Computed Centrality Measures

\begin{tabular}{lccc}
\hline & $(1)$ & $(2)$ & $(3)$ \\
& IPO Wave & Non- IPO Wave & $(1)-(2)$ \\
\hline Degree & 0.5807 & 0.3723 & $0.2084^{* *}$ \\
Eigenvector & 0.6727 & 0.4892 & $0.1835^{* *}$ \\
\hline Observations & 321 & 4251 & \\
\hline
\end{tabular}

The benchmark IO tables are produced every five years. The centrality measures are recomputed every five years to reflect the data in the tables. For example, the data in the 1987 IO tables is used to compute the centrality measures for the five years from 1987 to 1991. After that the 1992 IO table is used for the years 1992 to 1996 . The 1997 table is used for the period 1997 to 2001. The 2002 table is used for the years 2002 to 2006 . The 2007 table is used for the years from 2007 to 2011. Average values are reported in columns (1) and (2), and column (3) reports the difference between columns (1) and (2). The ** indicates statistical significance at the $1 \%$ level.

\section{Panel B) Other Variables}

\begin{tabular}{lcc}
\hline \multicolumn{1}{c}{ Variables } & $(1)$ & $(2)$ \\
\hline IPOWave & Mean & Standard Deviation \\
IPOnum & 0.0702 & 0.1763 \\
FF4F Alpha & 1.9068 & 5.4209 \\
Sretx & 0.0156 & 1.1422 \\
MB & 0.1482 & 0.0925 \\
Profit & 1.6262 & 1.8309 \\
Leverage & 0.0132 & 0.4406 \\
Tang & 0.1575 & 0.0944 \\
Capx & 0.2876 & 0.1529 \\
Size & 0.1872 & 0.0793 \\
Herfindahl & 4.8275 & 1.3702 \\
Industry Homogeneity & 0.3217 & 0.1744 \\
Industry Scope & 0.9182 & 1.9131 \\
AAA-10yr & 0.0029 & 0.0088 \\
& 1.1951 & 0.5063
\end{tabular}




\begin{tabular}{lll} 
Firms in Ind & 0.0396 & 0.0141 \\
Sales Ind & 0.0164 & 0.0147 \\
Mkt-rf & 0.0178 & 0.0331 \\
Stock Vol & 0.1482 & 0.0925 \\
GDP Growth & 2.8674 & 2.1667 \\
Invest Growth & 5.3571 & 7.0943 \\
Earn AR Disp & 0.0791 & 0.0234 \\
Analyst Disp & 0.0525 & 0.0119 \\
\hline
\end{tabular}

There are 4,572 observations. FF4F Alpha is the monthly four-factor Fama-French intercept one year before the IPO. Sretx is the volatility of the returns one year before the IPO. $M B$ is the median market-to-book ratio of the industry one year before the IPO. Profit is the median profitability of the industry one year before the IPO. Leverage is the median leverage of the industry one year before the IPO. Tang is the median tangibility of assets of the industry one year before the IPO. Capx is the median CAPX/AT of the industry one year before the IPO. Size is the median $\ln$ (total assets) of the industry one year before the IPO. Herfindahl reflects the concentration of the sales of the firms in that industry. Industry Homogeneity is the partial correlation of the monthly returns of the firms in that industry and is calculated on an annual basis. The method for the calculation comes from Parrino (1997). As in Ahern and Harford (2014), Industry Scope is the percentage of all SICs that map to an individual IO industry. AAA-10yr is the spread of the constant maturity of AAA-rated corporate bonds and the 10-year Treasury bond. This data is from https://research.stlouisfed.org/fred2/.Firms_in_Ind is the total number of firms at the end of the last calendar year in that industry divided by the total number of Compustat firms in that year. Sales Ind is the dollar value of the sales for that industry in the previous year divided by the total dollar value of sales of all firms in Compustat. Mkt-rf is the market return less the risk-free rate. This is the equity risk premium and uses the data from Fama-French's module in WRDS. Stock $\mathrm{Vol}$ is the average of the standard deviation in the stock returns of all firms in that industry. Monthly data is used to calculate the standard deviations. GDP Growth is the year over year percentage change in the real GDP. Invest Growth is the year over year percentage change in real private nonresidential fixed investment. Earn AR Disp is the standard deviation in abnormal stock returns on earnings announcements (one day prior to announcement to one day after announcement) in the last quarter of the fiscal year for the corporation. Analyst Disp is the average of the standard deviation of the analysts' recommendations about earnings per sharehe last quarter of the fiscal year of the corporation. 


\section{Table 3: Industry Network Centrality and IPO Waves}

\section{Panel A) Regression Analysis}

Dependent variable IPOwave is an indicator variable equal to one that signifies an IPO waves for the I-O industry. IPOnum is the number of IPOs in an IPO wave by I-O industry. Degree is a measure of centrality. Eigenvector is a measure of eigenvector centrality. The rest of the variables are defined in Panel C of Table 2. Columns (1) and (2) use industry fixed effects in the panel logit regression, columns (3) and (4) use industry fixed effects in an OLS regression, and columns (5) and (6) use the Cox Hazard model. Year dummies are included in all columns. Robust standard errors are reported below the coefficients. VIF represents Variance Inflation Factor. The * and ** indicate statistical significance at the $5 \%$ and $1 \%$ levels, respectively.

\begin{tabular}{|c|c|c|c|c|c|c|}
\hline Dep. Var.: & $\begin{array}{c}\text { (1) } \\
\text { IPOwave }\end{array}$ & $\begin{array}{c}\text { (2) } \\
\text { IPOwave }\end{array}$ & $\begin{array}{c}(3) \\
\text { IPOnum }\end{array}$ & $\begin{array}{c}\text { (4) } \\
\text { IPOnum }\end{array}$ & $\begin{array}{c}\text { (5) } \\
\text { IPOwave }\end{array}$ & $\begin{array}{c}\text { (6) } \\
\text { IPOwave }\end{array}$ \\
\hline \multirow[t]{2}{*}{ Degree } & 2.0952 & & 6.9544 & & 1.5388 & \\
\hline & $(0.3828)^{* *}$ & & $(2.5261)^{* *}$ & & $(0.3657)^{* *}$ & \\
\hline \multirow[t]{2}{*}{ Eigenvector } & & 2.4818 & & 8.3442 & & 1.8465 \\
\hline & & $(0.4410)^{* *}$ & & $(3.1483)^{* *}$ & & $(0.4259)^{* *}$ \\
\hline \multirow[t]{2}{*}{ FF4F Alpha } & 1.3702 & 1.3647 & 4.9376 & 4.8965 & 0.7802 & 0.7791 \\
\hline & $(0.8628)$ & $(0.8624)$ & $(5.8333)$ & $(5.8325)$ & (1.0572) & (1.0591) \\
\hline \multirow[t]{2}{*}{ Sretx } & 1.2819 & 1.2752 & 1.7245 & 1.7712 & 0.6380 & 0.6381 \\
\hline & $(0.7870)$ & $(0.7855)$ & (3.9167) & $(3.9162)$ & $(0.5021)$ & $(0.5005)$ \\
\hline \multirow[t]{2}{*}{$M B$} & 0.0399 & 0.0398 & 4.0781 & 4.1043 & 0.0328 & 0.0337 \\
\hline & $(0.0299)$ & $(0.0300)$ & $(0.8010)^{* *}$ & $(0.8015)^{* *}$ & $(0.0425)$ & $(0.0422)$ \\
\hline \multirow[t]{2}{*}{ Profit } & 1.4863 & 1.4512 & 1.0736 & 2.9849 & 2.3765 & 2.2840 \\
\hline & $(1.0255)$ & (1.0195) & $(5.3123)$ & $(5.3127)$ & (1.4072) & $(1.4032)$ \\
\hline \multirow[t]{2}{*}{ Leverage } & 0.2768 & 0.3125 & 0.3625 & 0.3311 & 0.7977 & 0.8150 \\
\hline & $(1.2174)$ & $(1.2167)$ & $(4.4718)$ & $(4.4701)$ & $(1.3757)$ & (1.3790) \\
\hline \multirow[t]{2}{*}{ Tang } & -1.1120 & -1.0918 & -8.8066 & -8.7403 & -0.5733 & -0.5864 \\
\hline & $(0.7965)$ & $(0.7942)$ & $(5.2479)$ & $(5.2486)$ & $(0.8190)$ & $(0.8205)$ \\
\hline \multirow[t]{2}{*}{ Capx } & 4.5914 & 4.5793 & 4.1684 & 4.1855 & 3.1923 & 3.1970 \\
\hline & $(1.0645)^{* *}$ & $(1.0654)^{* *}$ & $(4.3047)$ & $(4.3042)$ & $(1.0992)^{* *}$ & $(1.1014)^{* *}$ \\
\hline \multirow[t]{2}{*}{ Size } & -0.0698 & -0.0701 & -0.1704 & -0.1808 & -0.0746 & -0.0732 \\
\hline & $(0.0871)$ & $(0.0868)$ & $(0.4202)$ & $(0.4206)$ & $(0.0876)$ & $(0.0876)$ \\
\hline \multirow[t]{2}{*}{ Hot } & 3.4139 & 3.3919 & 5.8112 & 5.8272 & 0.5746 & 0.5681 \\
\hline & $(10.4374)$ & $(10.4367)$ & $(1.8574)^{* *}$ & $(1.8574)^{* *}$ & $(1.3488)$ & $(1.3685)$ \\
\hline \multirow[t]{2}{*}{ Herfindahl } & -0.5447 & -0.5126 & -2.4211 & -2.4650 & -0.6668 & -0.6478 \\
\hline & $(0.2807)$ & $(0.2801)$ & $(1.0974)^{*}$ & $(1.0973)^{*}$ & $(0.3588)$ & $(0.3588)$ \\
\hline Industry & 0.0258 & 0.0258 & 0.0074 & 0.0074 & 0.0391 & 0.0400 \\
\hline \multicolumn{7}{|l|}{ Homogeneity } \\
\hline & $(0.0356)$ & $(0.0359)$ & $(0.0284)$ & $(0.0284)$ & $(0.0673)$ & $(0.0683)$ \\
\hline \multirow[t]{2}{*}{ Industry Scope } & 41.9238 & 42.0074 & 33.0551 & 32.9427 & 31.2299 & 31.1868 \\
\hline & $(9.8228)^{* *}$ & $(9.7435)^{* *}$ & $(45.4478)$ & (45.4448) & $(6.6245)^{* *}$ & $(6.5884)^{* *}$ \\
\hline \multirow[t]{2}{*}{$A A A-10 y r$} & -5.7368 & -5.7052 & -1.0585 & -1.0433 & -0.7143 & -0.7277 \\
\hline & (17.9076) & (17.9065) & $(1.4751)$ & $(1.4752)$ & $(1.3840)$ & (1.4081) \\
\hline \multirow[t]{2}{*}{ Firms in Ind } & 8.1363 & 8.2833 & 7.5838 & 7.4435 & 3.1001 & 3.0638 \\
\hline & (15.5999) & (15.5710) & $(7.1678)$ & $(7.1638)$ & $(14.9601)$ & (14.9569) \\
\hline \multirow[t]{2}{*}{ Sales Ind } & -15.1009 & -15.3709 & -26.5443 & -24.4362 & -7.5345 & -7.8606 \\
\hline & (18.1082) & (18.1200) & (33.7750) & (33.7466) & (17.9743) & $(18.0695)$ \\
\hline \multirow[t]{2}{*}{$M k t-r f$} & 57.8330 & 57.5723 & 9.5252 & 9.4489 & 9.1357 & 9.0077 \\
\hline & $(130.6754)$ & (130.6668) & $(24.7802)$ & (24.7786) & (11.7928) & (12.0033) \\
\hline \multirow[t]{2}{*}{ Stock Vol } & -0.3872 & -0.3824 & -0.5067 & -0.5245 & -0.4147 & -0.4069 \\
\hline & $(0.6198)$ & $(0.6185)$ & $(2.6956)$ & $(2.6952)$ & $(2.4604)$ & $(2.4599)$ \\
\hline \multirow[t]{2}{*}{ GDP Growth } & 20.9392 & 20.7411 & 13.3614 & 13.3119 & 25.0789 & 25.0259 \\
\hline & (98.2229) & (98.2158) & $(39.2836)$ & $(39.2811)$ & $(28.4720)$ & $(28.9625)$ \\
\hline \multirow[t]{2}{*}{ Invest Growth } & 44.4099 & 44.1250 & 9.5252 & 9.3792 & 11.0766 & 11.0392 \\
\hline & $(147.8536)$ & (147.8443) & $(24.7802)$ & $(23.9481)$ & $(9.3815)$ & $(9.5472)$ \\
\hline Earn AR Disp & -10.1235 & -10.6881 & -10.7198 & -10.7365 & 3.9912 & 4.7509 \\
\hline
\end{tabular}




\begin{tabular}{|c|c|c|c|c|c|c|}
\hline \multirow{3}{*}{ Analyst Disp } & (17.9118) & (11.8980) & $(23.8671)$ & $(24.8668)$ & $(65.2616)$ & (66.3100) \\
\hline & 82.9681 & 82.8250 & 34.9559 & 34.9704 & 55.0323 & 54.4554 \\
\hline & (72.5327) & $(72.5170)$ & $(36.9630)$ & $(36.9625)$ & (41.1246) & $(41.7830)$ \\
\hline \multirow[t]{2}{*}{ Constant } & 0.2725 & 0.2569 & 0.4427 & 1.1870 & & \\
\hline & $(0.2391)$ & $(0.2401)$ & (1.1034) & $(1.4516)$ & & \\
\hline $\mathrm{LRChi}^{2}$ & 218.62 & 219.89 & & & 102.17 & 103.51 \\
\hline $\operatorname{Adj} . R^{2}$ & & & 0.51 & 0.51 & & \\
\hline Observations & 4572 & 4572 & 4572 & 4572 & 4572 & 4572 \\
\hline Number of I-O & 127 & 127 & 127 & 127 & 127 & 127 \\
\hline \multicolumn{7}{|l|}{ VIF } \\
\hline Degree & 1.1964 & & & & & \\
\hline Eigenvector & & 1.1913 & & & & \\
\hline
\end{tabular}

\section{Panel B) Importance of Different Factors}

The table reports the variation in IPOwave explained by each factor. Each row reports the logit regression of IPOwave and only one factor. The first row reports the estimates from the logit regression of IPOwave and Degree. Column (1) reports the odds ratio of the regression, Column (2) reports the z-statistics from the logit regression, Column (3) reports the Wald $\mathrm{Chi}^{2}$, and Column (4) reports the Bayesian Information Criteria (BIC) of the regression.

\begin{tabular}{lrcrc}
\hline & $(1)$ & \multicolumn{1}{c}{$(2)$} & \multicolumn{1}{c}{$(3)$} & $(4)$ \\
Dep. Var.: & Odds ratio & z-stat & \multicolumn{1}{c}{ Chi $^{2}$} & \multicolumn{1}{c}{ BIC } \\
\hline Degree & 12.8313 & $7.31^{* *}$ & 53.47 & 2225.615 \\
Eigenvector & 19.8023 & $7.43^{* *}$ & 55.19 & 2223.591 \\
FF4F Alpha & 4.1618 & $2.03^{*}$ & 4.14 & 2318.316 \\
Sretx & 4.3428 & $3.18^{* *}$ & 10.08 & 2311.561 \\
MB & 1.0001 & 0.03 & 0.00 & 2322.416 \\
Profit & 112.2704 & $3.84^{* *}$ & 14.78 & 2306.686 \\
Leverage & 1.0401 & 1.45 & 2.12 & 2320.258 \\
Tang & 0.4497 & 0.53 & 0.29 & 2322.129 \\
Capx & 163.0701 & $6.18^{* *}$ & 38.20 & 2289.190 \\
Size & 0.6720 & $-5.73^{* *}$ & 32.79 & 2286.767 \\
Hot & 1.7846 & $3.52^{* *}$ & 12.41 & 2311.106 \\
Herfindahl & 0.6252 & $-2.00^{*}$ & 3.99 & 2318.485 \\
Industry Homogeneity & 1.0052 & 0.30 & 0.09 & 2322.304 \\
Industry Scope & 22.3251 & $5.41^{* *}$ & 29.26 & 2292.538 \\
AAA-10yr & 0.5274 & $-4.74^{* *}$ & 22.47 & 2298.646 \\
Firms in Ind & 1.0010 & 0.72 & 0.52 & 2321.851 \\
Sales Ind & 0.0001 & -1.16 & 1.34 & 2320.604 \\
Mkt-rf & 1.0121 & $3.21 * *$ & 10.28 & 2266.283 \\
Stock Vol & 0.8265 & $-2.04^{*}$ & 4.15 & 2269.817 \\
GDP Growth & 10.601 & $3.88^{* *}$ & 15.05 & 2262.094 \\
Invest Growth & 1.7560 & 0.39 & 0.15 & 2276.52 \\
Earn AR Disp & 0.0004 & -1.45 & 2.12 & 2274.565 \\
Analyst Disp & 1.9838 & 0.18 & 0.03 & 2276.641 \\
\hline & & & & \\
\hline
\end{tabular}




\section{Table 4: Robustness: The Results Hold for Non-Hot Period}

The observations for the years 1997 to 2000 are dropped. Dependent variable IPOwave is an indicator variable equal to one that signifies IPO waves for an I-O industry. IPOnum is the number of IPOs in an IPO wave by I-O industry. Degree is a measure of centrality. Eigenvector is a measure of eigenvector centrality. The rest of the variables are defined in Panel C of Table 2. Columns (1) and (2) use fixed effects in a panel logit regression, columns (3) and (4) uses industry fixed effects in an OLS, and columns (5) and (6) use the Cox hazard model. Year dummies are included in all columns. Robust standard errors are reported below the coefficients. The * and ** indicate statistical significance at the $5 \%$ and $1 \%$ levels, respectively.

\begin{tabular}{|c|c|c|c|c|c|c|}
\hline Dep. Var.: & $\begin{array}{c}\text { (1) } \\
\text { IPOwave }\end{array}$ & $\begin{array}{c}\text { (2) } \\
\text { IPOwave }\end{array}$ & $\begin{array}{c}\text { (3) } \\
\text { IPOnum }\end{array}$ & $\begin{array}{c}\text { (4) } \\
\text { IPOnum }\end{array}$ & $\begin{array}{c}5) \\
\text { IPOwave }\end{array}$ & $\begin{array}{c}6) \\
\text { IPOwave }\end{array}$ \\
\hline Degree & $\begin{array}{c}1.9541 \\
(0.4411)^{* *}\end{array}$ & & $\begin{array}{r}6.1584 \\
(2.0707)^{* *}\end{array}$ & & $\begin{array}{c}1.4989 \\
(0.3921)^{* *}\end{array}$ & \\
\hline Eigenvector & & $\begin{array}{l}2.3205 \\
(0.5080)^{* *}\end{array}$ & & $\begin{array}{c}7.2207 \\
(2.5507)^{* *}\end{array}$ & & $\begin{array}{r}1.784 \\
(0.4583)^{* *}\end{array}$ \\
\hline FF4F Alpha & $\begin{array}{c}1.8850 \\
(1.2434)\end{array}$ & $\begin{array}{c}1.8824 \\
(1.2457)\end{array}$ & $\begin{array}{r}3.3568 \\
(5.6473)\end{array}$ & $\begin{array}{c}3.3131 \\
(5.6467)\end{array}$ & $\begin{array}{c}0.7411 \\
(1.4972)\end{array}$ & $\begin{array}{r}0.7414 \\
(1.5122)\end{array}$ \\
\hline Sretx & $\begin{array}{c}1.6844 \\
(0.8647)\end{array}$ & $\begin{array}{c}1.6814 \\
(0.8626)\end{array}$ & $\begin{array}{r}1.6227 \\
(4.4417)\end{array}$ & $\begin{array}{c}1.6724 \\
(4.4411)\end{array}$ & $\begin{array}{c}0.6955 \\
(0.5377)\end{array}$ & $\begin{array}{r}0.6961 \\
(0.5378)\end{array}$ \\
\hline$M B$ & $\begin{array}{c}0.0425 \\
(0.0387)\end{array}$ & $\begin{array}{c}0.0433 \\
(0.0386)\end{array}$ & $\begin{array}{r}2.2681 \\
(0.7936)^{* *}\end{array}$ & $\begin{array}{c}2.2854 \\
(0.7941)^{* *}\end{array}$ & $\begin{array}{c}0.0341 \\
(0.0417)\end{array}$ & $\begin{array}{r}0.0349 \\
(0.0415)\end{array}$ \\
\hline Profit & $\begin{array}{c}0.9950 \\
(1.4605)\end{array}$ & $\begin{array}{c}0.9232 \\
(1.4525)\end{array}$ & $\begin{array}{r}0.7086 \\
(5.0401)\end{array}$ & $\begin{array}{c}0.7620 \\
(5.0404)\end{array}$ & $\begin{array}{c}2.3704 \\
(1.5834)\end{array}$ & $\begin{array}{r}2.2914 \\
(1.5801)\end{array}$ \\
\hline Leverage & $\begin{array}{c}0.3807 \\
(1.4152)\end{array}$ & $\begin{array}{c}0.4147 \\
(1.4137)\end{array}$ & $\begin{array}{r}1.0665 \\
(4.2507)\end{array}$ & $\begin{array}{c}1.0329 \\
(4.2495)\end{array}$ & $\begin{array}{c}1.6193 \\
(1.4496)\end{array}$ & $\begin{array}{r}1.6343 \\
(1.4513)\end{array}$ \\
\hline Tang & $\begin{array}{l}-0.5028 \\
(0.8945)\end{array}$ & $\begin{array}{l}-0.4877 \\
(0.8919)\end{array}$ & $\begin{array}{r}-10.2991 \\
(5.0108)^{*}\end{array}$ & $\begin{array}{c}-10.3093 \\
(5.0096)^{*}\end{array}$ & $\begin{array}{l}-0.4202 \\
(0.8581)\end{array}$ & $\begin{array}{l}-0.4198 \\
(0.8588)\end{array}$ \\
\hline Capx & $\begin{array}{c}4.7605 \\
(1.2421)^{* *}\end{array}$ & $\begin{array}{l}4.7617 \\
(1.2422)^{* *}\end{array}$ & $\begin{array}{r}0.4516 \\
(4.1770)\end{array}$ & $\begin{array}{c}0.4290 \\
(4.1771)\end{array}$ & $\begin{array}{c}3.0863 \\
(1.2206) *\end{array}$ & $\begin{array}{r}3.1018 \\
(1.2228) *\end{array}$ \\
\hline Size & $\begin{array}{l}-0.0552 \\
(0.0968)\end{array}$ & $\begin{array}{l}-0.0549 \\
(0.0965)\end{array}$ & $\begin{array}{r}-0.0581 \\
(0.3992)\end{array}$ & $\begin{array}{l}-0.0524 \\
(0.3995)\end{array}$ & $\begin{array}{l}-0.0676 \\
(0.0920)\end{array}$ & $\begin{array}{r}-0.0661 \\
(0.0920)\end{array}$ \\
\hline Herfindahl & $\begin{array}{l}-0.7985 \\
(0.3245)^{*}\end{array}$ & $\begin{array}{l}-0.7699 \\
(0.3237)^{*}\end{array}$ & $\begin{array}{r}-0.5354 \\
(1.0470)\end{array}$ & $\begin{array}{l}-0.5754 \\
(1.0465)\end{array}$ & $\begin{array}{l}-0.6598 \\
(0.3983)\end{array}$ & $\begin{array}{r}-0.6407 \\
(0.3984)\end{array}$ \\
\hline $\begin{array}{l}\text { Industry } \\
\text { Homogeneity }\end{array}$ & $\begin{array}{c}0.0369 \\
(0.0424)\end{array}$ & $\begin{array}{c}0.0368 \\
(0.0426)\end{array}$ & $\begin{array}{r}0.0082 \\
(0.0252)\end{array}$ & $\begin{array}{c}0.0083 \\
(0.0252)\end{array}$ & 0.0665 & 0.0666 \\
\hline Industry Scope & $\begin{array}{c}45.4965 \\
(11.2077)^{* *}\end{array}$ & $\begin{array}{l}45.6216 \\
(11.1146)^{* *}\end{array}$ & $\begin{array}{r}34.0591 \\
(45.9485)\end{array}$ & $\begin{array}{c}33.9583 \\
(45.3856)\end{array}$ & $\begin{array}{c}29.0895 \\
(6.9962) * *\end{array}$ & $\begin{array}{r}29.1372 \\
(6.9495) * *\end{array}$ \\
\hline$A A A-10 y r$ & $\begin{array}{l}-2.9864 \\
(5.0799)\end{array}$ & $\begin{array}{l}-2.9801 \\
(5.0799)\end{array}$ & $\begin{array}{c}-0.5684 \\
(1.3146)\end{array}$ & $\begin{array}{l}-0.5608 \\
(1.3148)\end{array}$ & $\begin{array}{l}-0.7014 \\
(1.8867)\end{array}$ & $\begin{array}{r}-0.7127 \\
(1.9136)\end{array}$ \\
\hline Firms in Ind & $\begin{array}{c}0.7871 \\
(18.6316)\end{array}$ & $\begin{array}{c}0.6551 \\
(18.6039)\end{array}$ & $\begin{array}{r}109.6484 \\
(140.9199)\end{array}$ & $\begin{array}{c}109.2130 \\
(140.9174)\end{array}$ & $\begin{array}{c}0.9653 \\
(17.8960)\end{array}$ & $\begin{array}{r}0.9550 \\
(17.8994)\end{array}$ \\
\hline Sales Ind & $\begin{array}{l}-41.3750 \\
(35.1114)\end{array}$ & $\begin{array}{l}-42.6958 \\
(35.3427)\end{array}$ & $\begin{array}{r}-220.3618 \\
(317.4169)\end{array}$ & $\begin{array}{l}-219.9317 \\
(317.4020)\end{array}$ & $\begin{array}{l}-39.8189 \\
(37.5068)\end{array}$ & $\begin{array}{r}-41.2561 \\
(37.9438)\end{array}$ \\
\hline$M k t-r f$ & $\begin{array}{c}48.1991 \\
(116.9823)\end{array}$ & $\begin{array}{c}47.9654 \\
(116.9802)\end{array}$ & $\begin{array}{r}10.0494 \\
(14.4853)\end{array}$ & $\begin{array}{c}10.2481 \\
(18.8473)\end{array}$ & $\begin{array}{c}11.0036 \\
(15.9022)\end{array}$ & $\begin{array}{r}10.9300 \\
(16.1467)\end{array}$ \\
\hline Stock Vol & $\begin{array}{l}-0.6529 \\
(0.6017)\end{array}$ & $\begin{array}{l}-0.6503 \\
(0.6000)\end{array}$ & $\begin{array}{r}-0.7675 \\
(2.4962)\end{array}$ & $\begin{array}{l}-0.7843 \\
(2.4959)\end{array}$ & $\begin{array}{c}27.6723 \\
(31.9018)\end{array}$ & $\begin{array}{r}27.6847 \\
(32.3893)\end{array}$ \\
\hline GDP Growth & $\begin{array}{c}34.4272 \\
(145.8745)\end{array}$ & $\begin{array}{c}34.1835 \\
(145.8750)\end{array}$ & $\begin{array}{r}14.3875 \\
(28.5529)\end{array}$ & $\begin{array}{c}17.4958 \\
(19.4832)\end{array}$ & $\begin{array}{c}16.7481 \\
(17.0853)\end{array}$ & $\begin{array}{r}16.7133 \\
(17.2927)\end{array}$ \\
\hline Invest Growth & $\begin{array}{c}2.0535 \\
(3.1964)\end{array}$ & $\begin{array}{c}2.1421 \\
(3.1964)\end{array}$ & $\begin{array}{r}2.5958 \\
(4.4382)\end{array}$ & $\begin{array}{c}3.5947 \\
(4.9811)\end{array}$ & $\begin{array}{c}3.3728 \\
(5.6245)\end{array}$ & $\begin{array}{r}4.3183 \\
(7.0852)\end{array}$ \\
\hline Earn AR Disp & $\begin{array}{c}-44.0831 \\
(302.1870)\end{array}$ & $\begin{array}{c}-43.3377 \\
(302.1801)\end{array}$ & $\begin{array}{r}-12.8274 \\
(13.3651)\end{array}$ & $\begin{array}{l}-11.4621 \\
(14.3852)\end{array}$ & $\begin{array}{l}-16.8946 \\
(86.3138)\end{array}$ & $\begin{array}{r}-16.3850 \\
(87.4971)\end{array}$ \\
\hline Analyst Disp & $\begin{array}{c}32.8391 \\
(94.3119)\end{array}$ & $\begin{array}{c}32.3795 \\
(94.3054)\end{array}$ & $\begin{array}{r}26.8371 \\
(19.8472)\end{array}$ & $\begin{array}{c}23.4681 \\
(17.8437)\end{array}$ & $\begin{array}{c}11.0036 \\
(15.9022)\end{array}$ & $\begin{array}{r}10.9300 \\
(16.1467)\end{array}$ \\
\hline Constant & $\begin{array}{c}0.5314 \\
(0.2470)^{*}\end{array}$ & $\begin{array}{c}0.5170 \\
(0.2479)^{*}\end{array}$ & $\begin{array}{r}5.0080 \\
(4.9586)\end{array}$ & $\begin{array}{c}6.3947 \\
(5.2686)\end{array}$ & & \\
\hline
\end{tabular}




\begin{tabular}{|c|c|c|c|c|c|c|}
\hline LRChi $^{2}$ & 184.53 & 185.43 & & & 85.88 & 86.66 \\
\hline Adj. $\mathrm{R}^{2}$ & & & 0.52 & 0.52 & & \\
\hline Observations & 3872 & 3872 & 3872 & 3872 & 3872 & 3872 \\
\hline Number of I-O & 121 & 121 & 121 & 121 & 121 & 121 \\
\hline
\end{tabular}




\section{Table 5: Deregulatory Shocks and IPO Waves \\ Panel A) IPO Waves Before and After Industry Deregulations}

The sample consists of industries that experience deregulatory shocks. Of these industries all industries with a Degree value greater than the 75 percentile are included and coded as High Degree $=1$. Also, of the shocked industries, all industries with Eigenvector value greater than the $75^{\text {th }}$ percentile are included and coded as High Eigen $=1$. The rest of the industries are propensity score matched industries. The matching variables are size, year and profitability of the industry. The time period is five years before and five years after the shock. Shock is a dummy variable that takes the value of one if the observation-years are after an industry shock. There are 120 observations. Standard errors are robust. The * and ** indicate statistical significance at the 5\% and $1 \%$ levels, respectively.

\begin{tabular}{|c|c|c|c|c|c|c|c|}
\hline & \multicolumn{3}{|c|}{ Before Deregulations } & \multicolumn{3}{|c|}{ After Deregulations } & \multirow{2}{*}{$\begin{array}{c}\text { Diff-in-Diff } \\
(6)-(3) \\
(7)\end{array}$} \\
\hline & $\begin{array}{c}\text { Control } \\
\text { (1) }\end{array}$ & $\begin{array}{c}\text { Treated } \\
(2)\end{array}$ & $\begin{array}{c}(2)-(1) \\
(3)\end{array}$ & $\begin{array}{c}\text { Control } \\
(4)\end{array}$ & $\begin{array}{c}\text { Treated } \\
(5)\end{array}$ & $\begin{array}{c}(5)-(4) \\
(6)\end{array}$ & \\
\hline & \multicolumn{7}{|c|}{ Analysis Using High Degree } \\
\hline IPOwave & 0.021 & 0.012 & $-0.009 * *$ & 0.062 & 0.107 & $0.045 * *$ & $0.054 * *$ \\
\hline \multirow[t]{2}{*}{ IPOnum } & 0.464 & 0.001 & $-0.463 * *$ & 2.116 & 3.269 & $1.153 * *$ & $1.617 * *$ \\
\hline & \multicolumn{7}{|c|}{ Analysis Using High Eigen } \\
\hline IPOwave & 0.019 & 0.009 & $-0.010 * *$ & 0.051 & 0.097 & $0.047 * *$ & $0.057 * *$ \\
\hline IPOnum & 0.474 & 0.004 & $-0.470 * *$ & 1.706 & 2.869 & $1.163 * *$ & $1.633 * *$ \\
\hline
\end{tabular}

\section{Panel B) Diff-in-Diff Analysis}

The sample consists of industries that experience deregulatory shocks. All industries with a Degree value greater than the 75 percentile are included and coded as HighDegree $=1$. All industries with an Eigenvector value greater than the $75^{\text {th }}$ percentile are included and coded as HighEigen $=1$. The rest of the industries are propensity score matched industries. The matching variables are size, year, and profitability of the industry. The time period is five years before and five years after the shock. Shock is a dummy variable that takes the value of one if the observation years are after an industry shock. HighDegree * Shock is the interaction term of HighDegree and Shock. HighEigen * Shock is the interaction term of HighEigen and Shock. The rest of the variables are as defined in Table 2. Columns (1) and (2) use fixed effects in the logit regressions and column (3) and (4) use industry fixed effects in an OLS. Year dummies are included, but not reported. Standard errors are robust. The * and ** indicate statistical significance at the $5 \%$ and $1 \%$ levels, respectively.

(1) (2)

\begin{tabular}{lc} 
Dep. Var.: & IPOwave \\
\hline HighDegree & 0.9224 \\
& $(0.2813)^{* *}$ \\
HighDegree*Shock & 0.3995 \\
& $(0.0556)^{* *}$
\end{tabular}

HighEigen

HighEigen*Shock

Shock

$-0.0743$

(0.0430)

FF4F Alpha

1.2691

(0.8800)

Sretx

$M B$
0.7437

(0.5587)

0.0313

(0.0323) IPOwave

(3) IPOnum 1.4752

(1.1835)

1.2799

$(0.0532)^{* *}$

0.6194

$(0.2644)^{*}$

0.4474

$(0.0555)^{* *}$

$-0.1032$

$(0.0422)^{*}$

1.3338

(0.8706)

0.7317

(0.5604)

0.0311

(0.0325)
(4)

IPOnum

$\begin{array}{cc} & 0.8472 \\ & (0.2741)^{* *} \\ & 1.2910 \\ & (0.0533)^{* *} \\ -0.3083 & -0.3266 \\ (0.0397)^{* *} & (0.0401)^{* *} \\ 0.0067 & 0.0066 \\ (0.0300) & (0.0300) \\ 0.6646 & 0.6351 \\ (0.4148) & (0.4146) \\ -0.0005 & -0.0005 \\ (0.0029) & (0.0029)\end{array}$

0.8472

$0.2741)^{*}$

1.2910

$-0.3266$

$0.0401)^{* *}$

(0.0300)

$(0.4146)$

(0.0029) 


\begin{tabular}{|c|c|c|c|c|}
\hline Profit & $\begin{array}{c}2.9739 \\
(2.2301)\end{array}$ & $\begin{array}{c}2.8150 \\
(2.2254)\end{array}$ & $\begin{array}{c}0.0008 \\
(0.0118)\end{array}$ & $\begin{array}{c}0.0007 \\
(0.0118)\end{array}$ \\
\hline Leverage & $\begin{array}{c}0.2004 \\
(1.1430)\end{array}$ & $\begin{array}{c}0.3172 \\
(1.1404)\end{array}$ & $\begin{array}{c}0.3559 \\
(0.5599)\end{array}$ & $\begin{array}{c}0.3220 \\
(0.5597)\end{array}$ \\
\hline Tang & $\begin{array}{l}-0.3532 \\
(0.7611)\end{array}$ & $\begin{array}{l}-0.3282 \\
(0.7638)\end{array}$ & $\begin{array}{l}-0.3181 \\
(0.5931)\end{array}$ & $\begin{array}{l}-0.2214 \\
(0.5929)\end{array}$ \\
\hline Capx & $\begin{array}{c}3.5033 \\
(2.9595)\end{array}$ & $\begin{array}{l}3.6258 \\
(0.9597)^{* *}\end{array}$ & $\begin{array}{c}1.3821 \\
(0.6241)^{*}\end{array}$ & $\begin{array}{c}1.3932 \\
(0.6238)^{*}\end{array}$ \\
\hline Size & $\begin{array}{l}-0.2567 \\
(0.1813)\end{array}$ & $\begin{array}{l}-0.2451 \\
(0.2817)\end{array}$ & $\begin{array}{l}-0.1727 \\
(0.1466)\end{array}$ & $\begin{array}{l}-0.1741 \\
(0.1466)\end{array}$ \\
\hline Hot & $\begin{array}{c}0.2674 \\
(0.2613)\end{array}$ & $\begin{array}{c}0.2260 \\
(0.2630)\end{array}$ & $\begin{array}{c}0.2976 \\
(0.1404)^{*}\end{array}$ & $\begin{array}{c}0.2808 \\
(0.1403)^{*}\end{array}$ \\
\hline Herfindahl & $\begin{array}{l}-0.4087 \\
(0.2707)\end{array}$ & $\begin{array}{l}-0.4050 \\
(0.2716)\end{array}$ & $\begin{array}{l}-0.7871 \\
(0.6884)\end{array}$ & $\begin{array}{l}-0.7799 \\
(0.7884)\end{array}$ \\
\hline Industry Homogeneity & $\begin{array}{c}0.0167 \\
(0.0272)\end{array}$ & $\begin{array}{c}0.0175 \\
(0.0279)\end{array}$ & $\begin{array}{c}0.0005 \\
(0.0087)\end{array}$ & $\begin{array}{c}0.0006 \\
(0.0087)\end{array}$ \\
\hline Industry Scope & $\begin{array}{l}41.6680 \\
(9.9919) * *\end{array}$ & $\begin{array}{l}45.1950 \\
(9.9969)^{* *}\end{array}$ & $\begin{array}{l}64.9483 \\
(23.1749)^{* *}\end{array}$ & $\begin{array}{c}61.0494 \\
(25.8571)^{*}\end{array}$ \\
\hline$A A A-10 y r$ & $\begin{array}{l}-1.0216 \\
(1.3026)\end{array}$ & $\begin{array}{l}-1.0345 \\
(1.3035)\end{array}$ & $\begin{array}{l}-0.2302 \\
(0.2088)\end{array}$ & $\begin{array}{l}-0.2355 \\
(0.2088)\end{array}$ \\
\hline Firms in Ind & $\begin{array}{c}8.4175 \\
(14.6845)\end{array}$ & $\begin{array}{c}9.8562 \\
(14.5937)\end{array}$ & $\begin{array}{c}3.3929 \\
(10.3416)\end{array}$ & $\begin{array}{c}3.4149 \\
(10.3372)\end{array}$ \\
\hline Sales Ind & $\begin{array}{l}-15.8554 \\
(17.2820)\end{array}$ & $\begin{array}{l}-17.2869 \\
(17.3092)\end{array}$ & $\begin{array}{l}-10.4982 \\
(15.8844)\end{array}$ & $\begin{array}{l}-10.5439 \\
(15.8777)\end{array}$ \\
\hline$M k t-r f$ & $\begin{array}{l}5.0404 \\
(2.4974)^{*}\end{array}$ & $\begin{array}{c}5.1361 \\
(2.5023)^{*}\end{array}$ & $\begin{array}{c}0.9229 \\
(1.1128)\end{array}$ & $\begin{array}{c}0.9428 \\
(1.1124)\end{array}$ \\
\hline Stock Vol & $\begin{array}{c}-8.8578 \\
(14.6453)\end{array}$ & $\begin{array}{c}-8.9391 \\
(14.6763)\end{array}$ & $\begin{array}{l}-5.8857 \\
(4.0406)\end{array}$ & $\begin{array}{l}-5.9121 \\
(4.0397)\end{array}$ \\
\hline GDP Growth & $\begin{array}{c}2.6838 \\
(2.1465)\end{array}$ & $\begin{array}{c}12.6650 \\
(12.1534)\end{array}$ & $\begin{array}{c}2.9886 \\
(2.6738)\end{array}$ & $\begin{array}{c}2.9902 \\
(1.6735)\end{array}$ \\
\hline Invest Growth & $\begin{array}{c}13.4977 \\
(12.0232)\end{array}$ & $\begin{array}{c}13.3971 \\
(12.0740)\end{array}$ & $\begin{array}{c}18.5187 \\
(13.5291)\end{array}$ & $\begin{array}{c}18.4964 \\
(13.5276)\end{array}$ \\
\hline Earn AR Disp & $\begin{array}{l}-25.0213 \\
(17.1141)\end{array}$ & $\begin{array}{l}-24.6153 \\
(17.1463)\end{array}$ & $\begin{array}{l}-3.6520 \\
(2.6294)\end{array}$ & $\begin{array}{l}-3.4703 \\
(2.6283)\end{array}$ \\
\hline Analyst Disp & $\begin{array}{c}2.4155 \\
(1.3272)\end{array}$ & $\begin{array}{c}2.2811 \\
(1.3303)\end{array}$ & $\begin{array}{c}1.9485 \\
(1.6739)\end{array}$ & $\begin{array}{c}1.6482 \\
(1.8456)\end{array}$ \\
\hline Constant & $\begin{array}{c}0.3032 \\
(0.2321) \\
\end{array}$ & $\begin{array}{c}0.3124 \\
(0.2316) \\
\end{array}$ & $\begin{array}{l}2.0764 \\
(0.5975)^{* *}\end{array}$ & $\begin{array}{c}2.1025 \\
(0.5973) * *\end{array}$ \\
\hline $\mathrm{Chi}^{2} / \mathrm{R}^{2}$ & 132.47 & 140.43 & 48.76 & 45.76 \\
\hline Observations & 120 & 120 & 120 & 120 \\
\hline Number of I-O & 12 & 12 & 12 & 12 \\
\hline
\end{tabular}




\section{Table 6: Downstream Shocks and Upstream IPO Waves}

The sample consists of industries that experience deregulatory shocks. Of these industries all with a Degree greater than the $75^{\text {th }}$ percentile are included and coded as HighDegree $=1$. Also, of the shocked industries all with an Eigenvector greater than the $75^{\text {th }}$ percentile are included and coded as HighEigen $=1$. The rest of the industries are propensity score matched. The matching variables are size, year, and profitability of the industry. The dependent variable IPOWavel is a dummy variable that takes the value of one if any upstream industry experiences an IPO wave in a year, or zero otherwise. IPOnuml is the total number of IPOs experienced by the upstream industries in a year. The time period is five years before and five years after the shock. Shock is a dummy variable that takes the value of one if the observation-years are after an industry shock. HighDegree* Shock is the interaction term of high Degree and Shock. HighEigen* Shock is the interaction term of high Eigenvector and Shock. The rest of the variables are as defined in Table 2. Columns (1) and (2) use fixed effects in the logit regressions while column (3) and (4) use fixed effects in an OLS. Year dummies are included, but not reported. Standard errors are robust. The * and $* *$ indicate statistical significance at the $5 \%$ and $1 \%$ levels, respectively.
(1)
(2)
(3)

(4)

\begin{tabular}{|c|c|c|c|c|}
\hline Dep. Var.: & IPOwave1 & IPOwave1 & IPOnum1 & IPOnum1 \\
\hline \multirow[t]{2}{*}{ HighDegree } & 0.6636 & & 0.3289 & \\
\hline & $(0.2908)^{*}$ & & $(0.2761)$ & \\
\hline \multirow[t]{2}{*}{ HighDegree*Shock } & 0.3117 & & 0.3670 & \\
\hline & $(0.0603)^{* *}$ & & $(0.0604)^{* *}$ & \\
\hline \multirow[t]{2}{*}{ HighEigen } & & 0.6194 & & 0.5837 \\
\hline & & $(0.2644)^{*}$ & & $(0.2183)^{* *}$ \\
\hline \multirow[t]{2}{*}{ HighEigen*Shock } & & 0.4474 & & 1.2955 \\
\hline & & $(0.0555)^{* *}$ & & $(0.0837)^{* *}$ \\
\hline \multirow[t]{2}{*}{ Shock } & -0.0182 & -0.0538 & -0.3360 & -0.3650 \\
\hline & $(0.0484)$ & $(0.0480)$ & $(0.3667)$ & $(0.3678)$ \\
\hline \multirow[t]{2}{*}{ FF4F Alpha } & 1.1384 & 1.1786 & 0.7856 & 0.8218 \\
\hline & $(0.9265)$ & $(0.9173)$ & $(1.0036)$ & $(1.0031)$ \\
\hline \multirow[t]{2}{*}{ Sretx } & 1.4270 & 1.4212 & 1.1646 & 1.1026 \\
\hline & $(1.5592)$ & $(1.5593)$ & $(0.7698)$ & $(0.7694)$ \\
\hline \multirow[t]{2}{*}{$M B$} & 0.1384 & 0.1306 & 0.0138 & 0.0110 \\
\hline & $(0.1613)$ & $(0.1613)$ & $(0.0436)$ & $(0.0436)$ \\
\hline \multirow[t]{2}{*}{ Profit } & 3.5153 & 3.3175 & 0.3640 & 0.2954 \\
\hline & $(2.4330)$ & $(2.4317)$ & $(1.0451)$ & $(1.0447)$ \\
\hline \multirow[t]{2}{*}{ Leverage } & 0.8912 & 1.0008 & 0.0332 & 0.0523 \\
\hline & $(1.3145)$ & (1.3117) & $(1.2603)$ & $(1.2597)$ \\
\hline \multirow[t]{2}{*}{ Tang } & -0.9620 & -0.8951 & -0.0921 & -0.0874 \\
\hline & $(0.8563)$ & $(0.8595)$ & (1.1893) & $(1.1888)$ \\
\hline \multirow[t]{2}{*}{ Capx } & 3.9073 & 4.1288 & 2.9447 & 3.0237 \\
\hline & $(1.1831)^{* *}$ & $(1.1852)^{* *}$ & $(1.3141)^{*}$ & $(1.3131)^{*}$ \\
\hline \multirow[t]{2}{*}{ Size } & -0.1673 & -0.1501 & -0.2345 & -0.2376 \\
\hline & $(0.0904)$ & $(0.0908)$ & $(0.2075)$ & $(0.2074)$ \\
\hline \multirow[t]{2}{*}{ Hot } & 0.2104 & 0.1506 & 0.6268 & 0.5849 \\
\hline & $(0.2953)$ & $(0.2973)$ & $(0.2804)^{*}$ & $(0.2803)^{*}$ \\
\hline \multirow[t]{2}{*}{ Herfindahl } & -0.0203 & -0.0135 & -1.3137 & -1.3118 \\
\hline & $(0.3099)$ & $(0.3109)$ & $(1.3709)$ & $(1.3707)$ \\
\hline \multirow[t]{2}{*}{ Industry Homogeneity } & 0.0074 & 0.0081 & 0.0003 & 0.0001 \\
\hline & $(0.0280)$ & $(0.0295)$ & $(0.0156)$ & $(0.0155)$ \\
\hline \multirow[t]{2}{*}{ Industry Scope } & 34.3992 & 38.0025 & 38.5832 & 31.9325 \\
\hline & $(10.2942)^{* *}$ & $(10.2838) * *$ & $(20.4831)$ & $(18.3943)$ \\
\hline$A A A-10 y r$ & -0.4103 & -0.4180 & -0.1363 & -0.1504 \\
\hline
\end{tabular}




\begin{tabular}{lcccc} 
& $(0.4096)$ & $(0.4110)$ & $(0.2958)$ & $(0.2956)$ \\
Firms in Ind & 19.0807 & 20.1950 & 12.1166 & 12.4188 \\
Sales Ind & $(18.8366)$ & $(18.6828)$ & $(24.4193)$ & $(24.4066)$ \\
& -23.9069 & -25.5000 & -6.4759 & -6.8131 \\
Mkt-rf & $(21.2525)$ & $(21.2190)$ & $(32.0297)$ & $(32.0126)$ \\
& 4.9538 & 4.8459 & 0.0129 & -0.0038 \\
Stock Vol & $(3.4191)$ & $(3.4317)$ & $(2.5146)$ & $(2.5132)$ \\
& -8.8472 & -8.3821 & -4.59382 & -4.2921 \\
GDP Growth & $(9.4827)$ & $(10.8314)$ & $(4.9382)$ & $(4.9328)$ \\
& 21.3257 & 21.4686 & 5.7459 & 6.0201 \\
Invest Growth & $(7.8659)^{* *}$ & $(7.8635)^{* *}$ & $(6.0249)$ & $(6.0215)$ \\
& 6.2092 & 5.9819 & 10.0131 & 9.9904 \\
Earn AR Disp & $(6.2238)$ & $(6.2357)$ & $(8.2579)$ & $(8.2567)$ \\
& -9.8890 & -8.1063 & -6.1913 & -63.5048 \\
Analyst Disp & $(17.2228)$ & $(17.3182)$ & $(11.7140)$ & $(11.7090)$ \\
& 26.1561 & 24.9299 & 22.8874 & 21.9404 \\
Constant & $(19.3553)$ & $(19.4187)$ & $(17.9343)$ & $(17.9311)$ \\
& 0.2590 & 0.2636 & 5.5934 & 5.5449 \\
Chi ${ }^{2} / \mathrm{R}^{2}$ & $(0.2689)$ & $(0.2679)$ & $(1.6821)^{* *}$ & $(1.6813)^{* *}$ \\
\hline Observations & 174.84 & 177.83 & 53.92 & 53.97 \\
Number of I-O & 120 & 120 & 120 & 120 \\
\hline
\end{tabular}




\section{Table 7: Free Trade Agreement and IPO Waves Panel A) IPO Waves Before and After NAFTA}

The dependent variable IPOwave is an indicator variable equal to one that signifies an IPO wave for the I-O industry. Of these industries all with a Degree greater than the 75 percentile are included and coded as HighDegree 1 $=1$. Also, of the shocked industries all with an Eigenvector greater than the $75^{\text {th }}$ percentile are included and coded as HighEigen $1=1$. The rest of the industries are propensity score matched. The matching variables are size, year, and profitability of the industry. The time period is from 1986 to 1991 . The table contains 372 observations. The * and ** indicate statistical significance at the $5 \%$ and $1 \%$ levels, respectively.

\begin{tabular}{|c|c|c|c|c|c|c|c|}
\hline & \multicolumn{3}{|c|}{ Before NAFTA } & \multicolumn{3}{|c|}{ After NAFTA } & \multirow{2}{*}{$\begin{array}{c}\text { Diff-in-Diff } \\
\text { (6)-(3) } \\
\text { (7) }\end{array}$} \\
\hline & $\begin{array}{c}\text { Control } \\
\text { (1) }\end{array}$ & $\begin{array}{c}\text { Treated } \\
\text { (2) }\end{array}$ & $\begin{array}{c}(2)-(1) \\
(3)\end{array}$ & $\begin{array}{c}\text { Control } \\
\text { (4) }\end{array}$ & $\begin{array}{c}\text { Treated } \\
(5)\end{array}$ & $\begin{array}{c}(5)-(4) \\
(6)\end{array}$ & \\
\hline & \multicolumn{7}{|c|}{ Analysis Using HighDegree } \\
\hline IPOwave & 0.012 & 0.033 & 0.021 & 0.136 & 0.014 & $-0.122 * *$ & $43 * *$ \\
\hline & & & 0.151 & 3.243 & 1.587 & $-1.655^{* *}$ & $-1.806 * *$ \\
\hline & \multicolumn{7}{|c|}{ Analysis Using HighEigen } \\
\hline IPOw & 0.013 & 0.033 & 0.021 & 0.112 & 0.011 & $-0.101 * *$ & $-0.122 * *$ \\
\hline IPOnum & 0.433 & 0.586 & 0.153 & 2.642 & 1.314 & $-1.329 * *$ & $-1.482 * *$ \\
\hline
\end{tabular}

\section{Panel B) IPO Waves}

The dependent variable IPOwave is an indicator variable equal to one that signifies an IPO wave for the I-O industry. Of these industries all with a Degree greater than the 75 percentile are included and coded as HighDegree 1 $=1$. Also, of the shocked industries all with an Eigenvector greater than the 75th percentile are included and coded as HighEigen $1=1$. The rest of the industries are propensity score matched. The matching variables are size, year, and profitability of the industry. The time period is from 1986 to 1991 . HighDegree ${ }^{*}$ Post-FTA is the interaction term of high Degree and Shock. HighEigen ${ }^{*}$ Post-FTA is the interaction term of high Eigenvector and Shock. The rest of the variables are as defined in Table 2. Columns (1) and (2) use industry fixed effects in the logit regressions while column (3) and (4) use industry fixed effects in an OLS. Year dummies are included, but not reported. Standard errors are robust. The * and ** indicate statistical significance at the 5\% and $1 \%$ levels, respectively.

\begin{tabular}{lcccc} 
& $(1)$ & $(2)$ & $(3)$ & $(4)$ \\
Dep. Var.: & IPOwave & IPOwave & IPOnum & IPOnum \\
\hline HighDegreel & 1.2247 & & 0.8699 & \\
& $(0.6125)^{*}$ & & $(0.3821)^{*}$ & \\
HighDegree1 ${ }^{*}$ Post-FTA & -2.1796 & & -2.1882 & \\
& $(1.0536)^{*}$ & & $(1.0490)^{*}$ & \\
HighEigen1 & & 0.6583 & & 0.8637 \\
& & $(0.2557)^{*}$ & & $(0.2612)^{* *}$ \\
HighEigen1 ${ }^{*}$ Post-FTA & & -0.4474 & & -1.1311 \\
& & $(0.0555)^{* *}$ & & $(0.2755)^{* *}$ \\
Post-FTA & -0.1521 & -0.1081 & -0.9917 & -0.9985 \\
& $(3.3333)$ & $(3.3424)$ & $(0.6381)$ & $(0.6406)$ \\
FF4F Alpha & 3.5145 & 3.4338 & 1.3381 & 1.3721 \\
& $(3.5680)$ & $(3.5976)$ & $(1.3787)$ & $(1.3827)$ \\
Sretx & 1.4533 & 1.4174 & 0.5050 & 0.5034 \\
& $(1.6351)$ & $(1.6428)$ & $(0.7960)$ & $(0.7981)$ \\
MB & 0.4876 & 0.4952 & 0.0675 & 0.0746 \\
& $(0.4450)$ & $(0.4476)$ & $(0.3359)$ & $(0.3368)$ \\
Profit & 4.1746 & 4.2014 & 1.1809 & 0.9696
\end{tabular}




\begin{tabular}{|c|c|c|c|c|}
\hline & $(3.7056)$ & $(3.7112)$ & $(2.2561)$ & $(2.2625)$ \\
\hline \multirow[t]{2}{*}{ Leverage } & 3.1881 & 3.4673 & 0.7184 & 0.7370 \\
\hline & $(3.4460)$ & $(3.4497)$ & $(1.4281)$ & (1.4319) \\
\hline \multirow[t]{2}{*}{ Tang } & -1.4721 & -1.2423 & -0.4611 & -0.2530 \\
\hline & (1.8308) & $(1.8247)$ & $(1.5340)$ & $(1.5400)$ \\
\hline \multirow[t]{2}{*}{ Capx } & 4.7292 & 4.6982 & 0.7537 & 0.5940 \\
\hline & $(2.4898)$ & $(2.5076)$ & $(1.2596)$ & $(1.2634)$ \\
\hline \multirow[t]{2}{*}{ Size } & -0.0795 & -0.0962 & -0.0461 & -0.0353 \\
\hline & $(0.1907)$ & $(0.1911)$ & $(0.1739)$ & $(0.1746)$ \\
\hline \multirow[t]{2}{*}{ Herfindahl } & -0.1493 & -0.0956 & -0.1953 & -0.3380 \\
\hline & $(0.7972)$ & $(0.7999)$ & $(0.5150)$ & $(0.5149)$ \\
\hline \multirow[t]{2}{*}{ Industry Homogeneity } & 0.1109 & 0.1149 & 0.0056 & 0.0054 \\
\hline & $(0.1400)$ & $(0.1409)$ & $(0.0188)$ & $(0.0188)$ \\
\hline \multirow[t]{2}{*}{ Industry Scope } & 68.0861 & 72.3825 & 54.8774 & 61.0494 \\
\hline & $(19.4253)^{* *}$ & $(19.5237)^{* *}$ & $(23.1749)^{* *}$ & $(25.8571)^{*}$ \\
\hline \multirow[t]{2}{*}{$A A A-10 y r$} & -0.2763 & -0.3322 & -1.8402 & -1.8473 \\
\hline & $(5.5637)$ & (5.5799) & $(0.9660)$ & $(0.9686)$ \\
\hline \multirow[t]{2}{*}{ Firms in Ind } & 11.7291 & 9.0673 & 2.8824 & 2.1135 \\
\hline & $(30.0397)$ & $(9.9014)$ & $(2.0990)$ & $(2.2402)$ \\
\hline \multirow[t]{2}{*}{ Sales Ind } & -4.7159 & -6.9721 & -18.4595 & -19.3822 \\
\hline & (37.6616) & (37.7348) & (77.0903) & (77.2949) \\
\hline \multirow{2}{*}{$M k t-r f$} & 25.0622 & 25.3417 & 0.3249 & 0.3067 \\
\hline & (29.4258) & (29.5394) & $(5.0464)$ & (5.0599) \\
\hline \multirow[t]{2}{*}{ Stock Vol } & -9.4382 & -10.4761 & -9.4721 & -0.8372 \\
\hline & (10.3852) & $(0.9487)$ & $(0.8462)$ & $(0.9472)$ \\
\hline \multirow[t]{2}{*}{ GDP Growth } & 29.8978 & 30.3384 & 16.3162 & 16.2481 \\
\hline & $(35.7862)$ & $(35.8767)$ & (10.0963) & (10.1233) \\
\hline \multirow[t]{2}{*}{ Invest Growth } & 30.8691 & 30.8486 & 5.3010 & 5.3115 \\
\hline & (16.3405) & (16.3709) & (3.6973) & $(3.7072)$ \\
\hline \multirow[t]{2}{*}{ Earn AR Disp } & -25.0213 & -24.6153 & -3.6520 & -3.4703 \\
\hline & (17.1141) & (17.1463) & $(2.6294)$ & (2.6283) \\
\hline \multirow{2}{*}{ Analyst Disp } & 2.4155 & 2.2811 & 1.9485 & 1.6482 \\
\hline & $(1.3272)$ & (1.3303) & (1.6739) & $(1.8456)$ \\
\hline \multirow[t]{2}{*}{ Constant } & 1.1631 & 1.1913 & 4.2591 & 4.0587 \\
\hline & $(0.4212)^{* *}$ & $(0.4174)^{* *}$ & $(2.4472)$ & $(2.4550)$ \\
\hline $\mathrm{Chi}^{2} / \mathrm{R}^{2}$ & 18.06 & 20.41 & 0.67 & 0.67 \\
\hline Observations & 372 & 372 & 317 & 317 \\
\hline Number of I-O & 62 & 62 & 124 & 124 \\
\hline
\end{tabular}




\section{Table 8: IPO Waves and Customer IPOs}

\section{Panel A) Upstream IPO Waves}

The dependent variable IPOwave in columns (1)-(2) is an indicator variable equal to one that signifies an IPO wave for the I-O industry. The dependent variable IPOnum in columns (3)-(4) is the number of IPOs in the year for the I$\mathrm{O}$ industry. Odd numbered columns are ones with customers with an IPO wave, even columns have customers without IPO wave. The variables are as defined in Table 2. Columns (1) and (2) use fixed effects in the logit regressions and column (3) and (4) use industry fixed effects in an OLS. Standard errors are robust. Year dummies are used but not reported. The $*$ and $* *$ indicate statistical significance at the $5 \%$ and $1 \%$ levels, respectively.

\begin{tabular}{|c|c|c|c|c|}
\hline & (1) & (2) & (3) & (4) \\
\hline \multicolumn{5}{|l|}{ Customer } \\
\hline IPO Wave? & Yes & No & Yes & No \\
\hline Dep. Var.: & IPOwave & IPOwave & IPOnum & IPOnum \\
\hline \multirow[t]{2}{*}{ Degree } & 2.1007 & 0.0259 & 2.0899 & 0.0430 \\
\hline & $(0.4131)^{* *}$ & (1.2039) & $(0.9834)^{*}$ & $(0.3347)$ \\
\hline \multirow[t]{2}{*}{ FF4F Alpha } & 1.3300 & 1.9506 & 1.1717 & 0.0017 \\
\hline & $(0.8972)$ & $(3.4030)$ & $(1.1388)$ & $(0.0107)$ \\
\hline \multirow[t]{2}{*}{ Sretx } & 1.4536 & 0.4714 & 1.3586 & 0.0374 \\
\hline & $(0.5545)^{* *}$ & $(1.7947)$ & $(0.8485)$ & $(0.2246)$ \\
\hline \multirow[t]{2}{*}{$M B$} & 0.1312 & 0.0212 & 0.0104 & 0.0004 \\
\hline & $(0.0604)^{*}$ & $(0.0380)$ & $(0.0473)$ & $(0.0011)$ \\
\hline \multirow[t]{2}{*}{ Profit } & 3.2932 & 1.1250 & 0.2005 & 0.0003 \\
\hline & $(1.4434)^{*}$ & (1.6337) & $(1.1446)$ & $(0.0042)$ \\
\hline \multirow[t]{2}{*}{ Leverage } & 0.5753 & 1.8087 & 1.1400 & 0.3014 \\
\hline & $(1.3329)$ & $(2.5242)$ & $(1.3881)$ & $(0.2539)$ \\
\hline \multirow[t]{2}{*}{ Tang } & -0.9038 & -1.0483 & -0.6291 & -0.1913 \\
\hline & $(0.8834)$ & (1.6175) & $(1.3132)$ & $(0.2964)$ \\
\hline \multirow[t]{2}{*}{ Capx } & 5.0269 & 2.1664 & 4.7169 & 0.3011 \\
\hline & $(1.1843)^{* *}$ & $(2.1457)$ & $(1.4565)^{* *}$ & $(0.2922)$ \\
\hline \multirow[t]{2}{*}{ Size } & -0.1137 & -0.2910 & -0.1331 & -0.0736 \\
\hline & $(0.0926)$ & $(0.1691)$ & $(0.1202)$ & $(0.0214)^{* *}$ \\
\hline \multirow[t]{2}{*}{ Hot } & 0.2869 & 0.5786 & 0.7917 & 0.0585 \\
\hline & $(0.2870)$ & (0.6508) & $(0.2991)^{* *}$ & $(0.0733)$ \\
\hline \multirow[t]{2}{*}{ Herfindahl } & -0.2081 & -0.3821 & -0.0274 & -0.0382 \\
\hline & $(0.2778)$ & $(0.6372)$ & $(0.0392)$ & $(0.0843)$ \\
\hline \multirow[t]{2}{*}{ Industry Homogeneity } & 0.0015 & 0.0085 & 0.0134 & 0.0134 \\
\hline & $(0.0172)$ & $(0.0812)$ & $(0.0809)$ & $(0.0193)$ \\
\hline \multirow[t]{2}{*}{ Industry Scope } & 37.1683 & 70.1274 & 146.8674 & 37.2970 \\
\hline & $(9.0511)^{* *}$ & $(37.9292)$ & $(33.7575)^{* *}$ & $(8.0022) * *$ \\
\hline \multirow[t]{2}{*}{$A A A-10 y r$} & -0.4696 & -1.8031 & -0.3732 & -0.1010 \\
\hline & $(0.2122)^{*}$ & $(1.0302)$ & $(0.1289)^{* *}$ & $(0.0364)^{* *}$ \\
\hline \multirow[t]{2}{*}{ Firms in Ind } & 4.9858 & 4.7601 & 0.2284 & 1.0722 \\
\hline & $(9.9109)$ & $(4.3538)$ & $(9.9411)$ & $(4.8762)$ \\
\hline \multirow[t]{2}{*}{ Sales Ind } & -20.0452 & -20.5773 & -6.0755 & -4.1006 \\
\hline & $(22.2859)$ & $(44.1236)$ & (34.7904) & $(7.4686)$ \\
\hline \multirow[t]{2}{*}{$M k t-r f$} & 6.2553 & 12.2258 & 1.8132 & 1.0259 \\
\hline & $(3.2932)$ & $(4.8753)^{*}$ & $(2.7933)$ & $(0.5228)^{*}$ \\
\hline \multirow[t]{2}{*}{ Stock Vol } & -0.0000 & -0.0000 & -0.0000 & -0.0000 \\
\hline & $(0.0000)$ & $(0.0000)$ & $(0.0000)^{*}$ & $(0.0000)$ \\
\hline GDP Growth & 20.7930 & 9.9028 & 3.9454 & 0.8952 \\
\hline
\end{tabular}




\begin{tabular}{lcccc} 
& $(7.9211)^{* *}$ & $(8.3036)$ & $(6.4839)$ & $(0.9431)$ \\
Invest Growth & 16.9085 & 7.2629 & 10.8228 & 0.7944 \\
& $(3.1175)^{* *}$ & $(3.1075)^{*}$ & $(2.1290)^{* *}$ & $(0.3006)^{* *}$ \\
Earn AR Disp & -103.7321 & -33.1711 & -77.0428 & -5.7238 \\
& $(16.7068)^{* *}$ & $(17.8752)$ & $(12.8623)^{* *}$ & $(1.6158)^{* *}$ \\
Analyst Disp & 23.0308 & 29.4759 & 24.0627 & 2.5102 \\
& $(8.7909)^{* *}$ & $(11.9658)^{*}$ & $(8.3773)^{* *}$ & $(0.9940)^{*}$ \\
Constant & 0.4507 & 0.9238 & 6.6942 & 1.2073 \\
& $(0.2570)$ & $(0.4130)^{*}$ & $(1.9014)^{* *}$ & $(0.2862)^{* *}$ \\
\hline Chi $^{2} / \mathrm{R}^{2}$ & 103.6 & 26.17 & 0.53 & 0.43 \\
Observations & 1944 & 2628 & 1944 & 2628 \\
Number of I-O & 54 & 73 & 54 & 73 \\
\hline
\end{tabular}

\section{Panel B) Downstream IPO Waves}

The dependent variable IPOwave in columns (1)-(2) is an indicator variable equal to one that signifies an IPO wave for the I-O industry. The dependent variable IPOnum in columns (3)-(4) is the number of IPOs in the year for the I$\mathrm{O}$ industry. Odd numbered columns are ones with customers with an IPO wave, even columns have customers without IPO wave. The variables are as defined in Table 2. Columns (1) and (2) use fixed effects in the logit regressions and column (3) and (4) use industry fixed effects in an OLS. Standard errors are robust. Year dummies are used but not reported. The $*$ and $* *$ indicate statistical significance at the $5 \%$ and $1 \%$ levels, respectively.

\begin{tabular}{lcccc}
\hline Supplier & $(1)$ & $(2)$ & $(3)$ & $(4)$ \\
IPO Wave? & Yes & No & Yes & No \\
Dep. Var.: & IPOwave & IPOwave & IPOnum & IPOnum \\
\hline Degree & 1.5869 & 1.4577 & 0.7338 & 0.6519 \\
FF4F Alpha & $(0.5788)^{* *}$ & $(0.5109)^{* *}$ & $(0.2253)^{* *}$ & $(0.2432)^{* *}$ \\
& 1.2031 & 2.2385 & 0.8617 & 0.0026 \\
Sretx & $(0.9126)$ & $(9.8295)$ & $(0.7078)$ & $(0.0080)$ \\
& 1.0478 & 3.6932 & 1.0770 & 0.5621 \\
MB & $(0.5111)^{*}$ & $(6.7047)$ & $(0.5538)$ & $(0.2393)^{*}$ \\
& 0.0282 & 0.4742 & 0.0083 & 0.0005 \\
Profit & $(0.0334)$ & $(1.2916)$ & $(0.0214)$ & $(0.0008)$ \\
& 1.9405 & 10.4438 & 0.2150 & 0.0005 \\
Leverage & $(1.2713)$ & $(9.8871)$ & $(0.5574)$ & $(0.0031)$ \\
Tang & 0.3750 & 4.6067 & 0.9488 & 0.0071 \\
& $(1.1914)$ & $(6.6532)$ & $(0.8129)$ & $(0.2491)$ \\
Capx & -0.4651 & -1.0702 & -0.5499 & -0.0816 \\
Size & $(0.8072)$ & $(3.8179)$ & $(0.8227)$ & $(0.2924)$ \\
& 5.0426 & 4.3257 & 2.8151 & 0.0122 \\
Hot & $(1.0542)^{* *}$ & $(7.8717)$ & $(0.8931)^{* *}$ & $(0.2858)$ \\
& -0.1844 & -0.0807 & -0.1510 & -0.0977 \\
Herfindahl & $(0.0838)^{*}$ & $(0.4667)$ & $(0.0696)^{*}$ & $(0.0207)^{* *}$ \\
& 0.1302 & 0.0937 & 0.2040 & 0.0056 \\
Industry Homogeneity & $(0.2806)$ & $(0.3615)$ & $(0.2014)$ & $(0.8447)$ \\
& -0.4564 & -0.3762 & -0.0382 & -0.0284 \\
& $(0.2533)$ & $(0.5327)$ & $(0.0429)$ & $(0.0395)$ \\
& 0.0104 & 0.0094 & 0.0125 & 0.0174 \\
& $(0.0252)$ & $(0.0074)$ & $(0.0385)$ & $(0.0284)$ \\
& & & &
\end{tabular}




\begin{tabular}{lcccc} 
Industry Scope & 37.1683 & 42.9481 & 76.9312 & 32.9481 \\
& $(9.0511)^{* *}$ & $(43.9581)$ & $(32.4981)^{*}$ & $(14.9382)^{*}$ \\
AAA-10yr & -0.4696 & -1.8031 & -0.3732 & -0.1010 \\
& $(0.2122)^{*}$ & $(1.0302)$ & $(0.1289)^{* *}$ & $(0.0364)^{* *}$ \\
Firms in Ind & 1.0716 & 35.1220 & 0.3556 & 0.8033 \\
& $(15.6665)$ & $(175.9670)$ & $(15.9276)$ & $(4.7910)$ \\
Sales Ind & -10.9631 & -292.4801 & -10.3429 & -3.6807 \\
& $(18.7254)$ & $(480.1035)$ & $(21.2059)$ & $(8.3972)$ \\
Mkt-rf & 3.7811 & 31.2748 & 2.2134 & 0.6025 \\
& $(2.7683)$ & $(40.8265)$ & $(1.6364)$ & $(0.5749)$ \\
Stock Vol & -0.0000 & -0.0000 & -0.0000 & -0.0000 \\
& $(0.0000)$ & $(0.0000)$ & $(0.0000)^{*}$ & $(0.0000)$ \\
GDP Growth & 10.0413 & 136.6970 & 2.5710 & 3.0786 \\
& $(6.9147)$ & $(120.6815)$ & $(3.7812)$ & $(0.9339)^{* *}$ \\
Invest Growth & 5.0005 & 1.0305 & 6.8376 & 0.7207 \\
& $(2.8349)^{* *}$ & $(8.2469)$ & $(1.2435)^{* *}$ & $(0.2845)^{*}$ \\
Earn AR Disp & -4.9590 & -11.8500 & -46.3929 & -0.3884 \\
& $(5.1245)$ & $(9.0075)$ & $(7.3989)^{* *}$ & $(1.5710)$ \\
Analyst Disp & 17.6038 & 28.9164 & 6.1042 & 1.0260 \\
& $(8.5549)^{*}$ & $(65.6870)$ & $(5.3910)$ & $(0.8365)$ \\
Constant & 0.4489 & 1.4371 & 4.1356 & 0.5820 \\
& $(0.2220)^{*}$ & $(1.0440)$ & $(1.0794)^{* *}$ & $(0.2822)^{*}$ \\
\hline Chi'/ R ${ }^{2}$ & 151.9 & 39.7 & 0.57 & 0.43 \\
Observations & 3154 & 1418 & 3154 & 1418 \\
Number of I-O & 88 & 39 & 88 & 39 \\
\hline
\end{tabular}

\section{Panel C: Upstream Industry Centrality and Propagation of IPO Waves}

The sample consists of industries whose customer's industry experiences an IPO wave. Odd numbered columns are supplier industries with a Degree greater than the median, even numbered columns have supplier industries with a Degree less than the median. The dependent variable IPOwave in columns (1)-(2) is an indicator variable equal to one that signifies an IPO wave in the I-O industry. The dependent variable IPOnum in columns (3)-(4) is the number of IPOs in the year in the I-O industry. The variables are as defined in Table 2. Columns (1) and (2) use industry fixed effects in the logit regressions while column (3) and (4) use industry fixed effects in an OLS. Standard errors are robust. Year dummies are used but not reported. The * and ** indicate statistical significance at the 5\% and $1 \%$ levels, respectively.

\begin{tabular}{lcccc}
\hline Degree>Median & $(1)$ & $(2)$ & $(3)$ & $(4)$ \\
Dep. Var.: & Yes & No & $\begin{array}{c}\text { Yes } \\
\text { IPOnum }\end{array}$ & $\begin{array}{c}\text { No } \\
\text { IPOnum }\end{array}$ \\
\hline Degree & IPOwave & IPOwave & 0.8950 & -0.3103 \\
& 0.1321 & 0.0261 & $(0.3458)^{* *}$ & $(3.0656)$ \\
FF4F Alpha & $(0.0441)^{* *}$ & $(0.0160)$ & 0.0041 & 1.1578 \\
& 0.0005 & 0.1446 & $(0.0170)$ & $(3.9226)$ \\
Sretx & $(0.0001)^{* *}$ & $(0.1322)$ & 0.1786 & 3.4796 \\
& 0.0484 & 0.1558 & $(0.2599)$ & $(3.0430)$ \\
MB & $(0.0212)^{*}$ & $(0.1250)$ & 0.0004 & 1.2082 \\
& 0.0001 & 0.0162 & $(0.0017)$ & $(0.5143)^{*}$ \\
Profit & $(0.0001)$ & $(0.0195)$ & 0.0003 & 0.8183
\end{tabular}




\begin{tabular}{|c|c|c|c|c|}
\hline & $(0.0001)$ & $(0.0933)$ & $(0.0068)$ & (3.5386) \\
\hline \multirow[t]{2}{*}{ Leverage } & 0.0181 & 0.0008 & 0.7455 & 2.3592 \\
\hline & $(0.0236)$ & $(0.1058)$ & $(0.3426)^{*}$ & $(3.8233)$ \\
\hline \multirow[t]{2}{*}{ Tang } & -0.0186 & -0.0314 & -0.2376 & -0.7363 \\
\hline & $(0.0199)$ & $(0.0668)$ & $(0.3825)$ & $(3.3822)$ \\
\hline \multirow[t]{2}{*}{ Capx } & 0.0997 & 0.1713 & 0.0515 & 10.3407 \\
\hline & $(0.0339)^{* *}$ & $(0.1257)$ & $(0.4008)$ & $(3.4695)^{* *}$ \\
\hline \multirow[t]{2}{*}{ Size } & -0.0040 & -0.0009 & -0.1057 & -0.0128 \\
\hline & $(0.0017)^{*}$ & $(0.0103)$ & $(0.0299)^{* *}$ & $(0.2827)$ \\
\hline \multirow[t]{2}{*}{ Hot } & 0.0007 & 0.0562 & 0.0426 & 1.9779 \\
\hline & $(0.0082)$ & $(0.0333)$ & $(0.0892)$ & $(0.7701)^{*}$ \\
\hline \multirow[t]{2}{*}{ Herfindahl } & -0.0069 & -0.0095 & -0.5923 & -0.8951 \\
\hline & $(0.0079)$ & $(0.0272)$ & $(0.1361)^{* *}$ & $(0.8427)$ \\
\hline \multirow[t]{2}{*}{ Industry Homogeneity } & 0.0002 & 0.0002 & 0.0019 & 0.0035 \\
\hline & $(0.0002)$ & $(0.0006)$ & $(0.0069)$ & $(0.0277)$ \\
\hline \multirow[t]{2}{*}{ Industry Scope } & 3.3417 & 1.7296 & 5.7361 & 5.8371 \\
\hline & $(1.0491)^{* *}$ & $(0.4644)^{* *}$ & $(4.9281)$ & $(8.4921)$ \\
\hline \multirow[t]{2}{*}{$A A A-10 y r$} & -0.0102 & -0.0023 & -0.1787 & -0.3901 \\
\hline & $(0.0042)^{*}$ & $(0.0141)$ & $(0.0715)^{*}$ & $(0.6191)$ \\
\hline \multirow[t]{2}{*}{ Firms in Ind } & 0.1051 & 0.1740 & 0.7306 & 18.0104 \\
\hline & $(0.2185)$ & $(0.5171)$ & $(6.3214)$ & (229.6443) \\
\hline \multirow[t]{2}{*}{ Sales Ind } & -0.1361 & -0.6358 & -5.9800 & -30.9469 \\
\hline & $(0.1740)$ & $(1.7418)$ & $(9.2052)$ & (522.3836) \\
\hline \multirow[t]{2}{*}{$M k t-r f$} & 0.0320 & 0.1735 & 0.0420 & 3.3791 \\
\hline & $(0.0555)$ & $(0.2346)$ & $(0.7169)$ & $(6.2341)$ \\
\hline \multirow[t]{2}{*}{ Stock Vol } & -0.0000 & -0.0000 & -0.0000 & -0.0000 \\
\hline & $(0.0000)$ & $(0.0000)$ & $(0.0000)^{* *}$ & $(0.0000)^{*}$ \\
\hline \multirow[t]{2}{*}{ GDP Growth } & 0.1422 & 1.0521 & 2.3377 & 19.5916 \\
\hline & $(0.0850)$ & $(0.4283)^{*}$ & $(1.3742)$ & (11.9919) \\
\hline \multirow[t]{2}{*}{ Invest Growth } & 0.0754 & 0.3743 & 1.2922 & 9.9597 \\
\hline & $(0.0279)^{* *}$ & $(0.1322)^{* *}$ & $(0.4364)^{* *}$ & $(3.8906)^{*}$ \\
\hline \multirow[t]{2}{*}{ Earn AR Disp } & -0.6052 & -1.4419 & -10.5339 & -43.0918 \\
\hline & $(0.1998)^{* *}$ & $(0.7935)$ & $(2.3370)^{* *}$ & $(20.3577)^{*}$ \\
\hline \multirow[t]{2}{*}{ Analyst Disp } & 0.0887 & 0.9121 & 0.6953 & 18.2600 \\
\hline & $(0.0920)$ & $(0.3685)^{*}$ & $(1.7049)$ & (14.9846) \\
\hline \multirow[t]{2}{*}{ Constant } & 0.0428 & 0.0227 & 1.0385 & 1.8170 \\
\hline & $(0.0203)^{*}$ & $(0.0880)$ & $(0.4033)^{*}$ & $(15.8590)$ \\
\hline $\mathrm{Chi}^{2} / \mathrm{R}^{2}$ & 38.29 & 31.17 & 0.57 & 0.53 \\
\hline Observations & 972 & 972 & 972 & 972 \\
\hline Number of I-O & 27 & 27 & 27 & 27 \\
\hline
\end{tabular}




\section{Panel D: Downstream Industry Centrality and Propagation of IPO Waves}

The sample consists of industries whose customer's industry experiences an IPO wave. Odd numbered columns are supplier industries with a Degree greater than the median, even numbered columns have supplier industries with a Degree less than the median. The dependent variable IPOwave in columns (1)-(2) is an indicator variable equal to one that signifies an IPO wave in the I-O industry. The dependent variable IPOnum in columns (3)-(4) is the number of IPOs in the year in the I-O industry. The variables are as defined in Table 2. Columns (1) and (2) use industry fixed effects in the logit regressions while column (3) and (4) use industry fixed effects in an OLS. Standard errors are robust. Year dummies are used but not reported. The * and ** indicate statistical significance at the 5\% and $1 \%$ levels, respectively.

\begin{tabular}{|c|c|c|c|c|}
\hline & (1) & (2) & (3) & (4) \\
\hline Degree $>$ Median & Yes & No & Yes & No \\
\hline Dep. Var.: & IPOwave & IPOwave & IPOnum & IPOnum \\
\hline \multirow[t]{2}{*}{ Degree } & 0.0586 & -0.1070 & 1.3158 & -2.3001 \\
\hline & $(0.0493)$ & $(0.1408)$ & $(0.9816)$ & $(1.1207)^{*}$ \\
\hline \multirow[t]{2}{*}{ FF4F Alpha } & 0.0452 & 0.0003 & 0.2661 & 0.0004 \\
\hline & $(0.0375)$ & $(0.0001)^{*}$ & (1.1613) & $(0.0112)$ \\
\hline \multirow[t]{2}{*}{ Sretx } & 0.0811 & 0.0177 & 1.0982 & 0.0557 \\
\hline & $(0.0417)$ & $(0.0189)$ & $(0.8149)$ & $(0.2628)$ \\
\hline \multirow[t]{2}{*}{$M B$} & 0.0349 & 0.0000 & 1.0884 & 0.0005 \\
\hline & $(0.0153)^{*}$ & $(0.0000)^{*}$ & $(0.2441)^{* *}$ & $(0.0011)$ \\
\hline \multirow[t]{2}{*}{ Profit } & 0.0566 & 0.0001 & 0.9879 & 0.0003 \\
\hline & $(0.0642)$ & $(0.0000)^{*}$ & $(1.5810)$ & $(0.0045)$ \\
\hline \multirow[t]{2}{*}{ Leverage } & 0.0293 & 0.0280 & 0.6289 & 0.1226 \\
\hline & $(0.0457)$ & $(0.0279)$ & $(1.2319)$ & $(0.2945)$ \\
\hline \multirow[t]{2}{*}{ Tang } & -0.0370 & -0.0129 & -0.7275 & 0.4141 \\
\hline & $(0.0374)$ & $(0.0184)$ & $(1.3214)$ & $(0.3223)$ \\
\hline \multirow[t]{2}{*}{ Capx } & 0.1395 & 0.0654 & 2.6689 & 0.5502 \\
\hline & $(0.0652)^{*}$ & $(0.0390)$ & $(1.4222)$ & $(0.3313)$ \\
\hline \multirow[t]{2}{*}{ Size } & -0.0045 & -0.0028 & -0.2391 & -0.1019 \\
\hline & $(0.0040)$ & $(0.0016)$ & $(0.1119)^{*}$ & $(0.0253)^{* *}$ \\
\hline \multirow[t]{2}{*}{ Hot } & 0.0176 & 0.0065 & 0.8453 & 0.0179 \\
\hline & $(0.0160)$ & $(0.0085)$ & $(0.2979)^{* *}$ & $(0.0751)$ \\
\hline \multirow[t]{2}{*}{ Herfindahl } & -0.0216 & -0.0104 & -1.2376 & -0.0888 \\
\hline & $(0.0133)$ & $(0.0107)$ & $(0.3552)^{* *}$ & $(0.1506)$ \\
\hline \multirow[t]{2}{*}{ Industry Homogeneity } & 0.0003 & 0.0000 & 0.0010 & 0.0014 \\
\hline & $(0.0003)$ & $(0.0002)$ & $(0.0148)$ & $(0.0063)$ \\
\hline \multirow[t]{2}{*}{ Industry Scope } & 2.1234 & 3.1762 & 3.8284 & 4.9281 \\
\hline & $(0.6485)^{* *}$ & $(0.7463)^{* *}$ & $(2.9841)$ & $(4.0962)$ \\
\hline \multirow[t]{2}{*}{$A A A-10 y r$} & -0.0081 & -0.0079 & -0.2777 & -0.1708 \\
\hline & $(0.0074)$ & $(0.0050)$ & $(0.2376)$ & $(0.0636)^{* *}$ \\
\hline \multirow[t]{2}{*}{ Firms in Ind } & 0.1669 & 0.0546 & 9.7378 & -1.0873 \\
\hline & $(0.4782)$ & $(0.1492)$ & $(36.1205)$ & $(4.5905)$ \\
\hline \multirow[t]{2}{*}{ Sales Ind } & -0.1043 & -0.1471 & -43.7814 & -0.1462 \\
\hline & $(0.3803)$ & $(0.1290)$ & $(62.3101)$ & $(7.6003)$ \\
\hline \multirow[t]{2}{*}{$M k t-r f$} & 0.1167 & 0.0131 & 1.0379 & 0.6256 \\
\hline & $(0.0934)$ & $(0.0717)$ & $(2.3056)$ & $(0.6315)$ \\
\hline \multirow[t]{2}{*}{ Stock Vol } & -0.0000 & -0.0000 & -0.0000 & -0.0000 \\
\hline & $(0.0000)$ & $(0.0000)$ & $(0.0000)^{*}$ & $(0.0000)^{* *}$ \\
\hline \multirow[t]{2}{*}{ GDP Growth } & 0.5088 & 0.0377 & 8.4544 & 1.0889 \\
\hline & $(0.1694)^{* *}$ & $(0.0976)$ & $(4.2272)^{*}$ & $(1.2852)$ \\
\hline
\end{tabular}




\begin{tabular}{lcccc} 
Invest Growth & 0.2409 & 0.0315 & 5.9335 & 0.4572 \\
& $(0.0562)^{* *}$ & $(0.0346)$ & $(1.4640)^{* *}$ & $(0.3839)$ \\
Earn AR Disp & -1.2464 & -0.4271 & -29.1293 & -3.4681 \\
& $(0.3461)^{* *}$ & $(0.2178)$ & $(7.9174)^{* *}$ & $(2.1402)$ \\
Analyst Disp & 0.4124 & 0.1204 & 8.8693 & 0.6747 \\
& $(0.1639)^{*}$ & $(0.1083)$ & $(5.5702)$ & $(1.4954)$ \\
Constant & 0.0234 & 0.0374 & 1.8820 & 1.5468 \\
& $(0.0363)$ & $(0.0216)$ & $(1.8001)$ & $(0.4233)^{* *}$ \\
\hline Chi $^{2} / \mathrm{R}^{2}$ & 307.61 & 110.01 & 0.43 & 0.38 \\
Observations & 1577 & 1577 & 1577 & 1577 \\
Number of I-O & 44 & 44 & 44 & 44 \\
\hline
\end{tabular}




\section{Table 9: Speed with which IPO Waves Move Upstream}

The sample consists of industries whose customer's industry experiences an IPO wave. Odd numbered columns are supplier industries with a Degree greater than the median, even numbered columns have supplier industries with a Degree less than the median. The dependent variable IPOwave in columns (1)-(2) is an indicator variable equal to one that signifies an IPO wave in the I-O industry. The dependent variable IPOnum in columns (3)-(4) is the number of IPOs in the year in the I-O industry. The variables are as defined in Table 2. Columns (1) and (2) use industry fixed effects in the logit regressions while column (3) and (4) use industry fixed effects in an OLS. Standard errors are robust. Year dummies are used but not reported. The * and ** indicate statistical significance at the 5\% and $1 \%$ levels, respectively.

\begin{tabular}{|c|c|c|c|c|}
\hline $\begin{array}{l}\text { Degree>Median } \\
\text { Dep. Var.: }\end{array}$ & $\begin{array}{c}\text { (1) } \\
\text { Yes } \\
\text { IPOwave }\end{array}$ & $\begin{array}{c}(2) \\
\text { No } \\
\text { IPOwave }\end{array}$ & $\begin{array}{c}\text { (3) } \\
\text { Yes } \\
\text { IPOnum }\end{array}$ & $\begin{array}{c}(4) \\
\text { No } \\
\text { IPOnum }\end{array}$ \\
\hline Time & $\begin{array}{l}0.6232 \\
(0.0252)^{* *}\end{array}$ & $\begin{array}{r}0.1727 \\
(0.3390)\end{array}$ & $\begin{array}{l}2.7341 \\
(0.4367)^{* *}\end{array}$ & $\begin{array}{r}1.0611 \\
(0.6258)\end{array}$ \\
\hline Time*Time & $\begin{array}{l}-0.1411 \\
(0.0095)^{* *}\end{array}$ & $\begin{array}{r}0.0933 \\
(0.0816)\end{array}$ & $\begin{array}{l}-0.4981 \\
(0.0684) * *\end{array}$ & $\begin{array}{r}0.2054 \\
(0.1450)\end{array}$ \\
\hline FF4F Alpha & $\begin{array}{l}0.0003 \\
(0.0001)^{* *}\end{array}$ & $\begin{array}{r}0.0049 \\
(0.0472)\end{array}$ & $\begin{array}{r}0.0037 \\
(0.0152)\end{array}$ & $\begin{array}{r}0.3365 \\
(2.8553)\end{array}$ \\
\hline Sretx & $\begin{array}{l}0.0436 \\
(0.0158)^{* *}\end{array}$ & $\begin{array}{r}0.0631 \\
(0.0508)\end{array}$ & $\begin{array}{r}0.2889 \\
(0.2287)\end{array}$ & $\begin{array}{r}0.8926 \\
(2.2311)\end{array}$ \\
\hline$M B$ & $\begin{array}{r}0.0000 \\
(0.0000)\end{array}$ & $\begin{array}{r}0.0046 \\
(0.0082)\end{array}$ & $\begin{array}{r}0.0003 \\
(0.0015)\end{array}$ & $\begin{array}{r}0.1460 \\
(0.4029)\end{array}$ \\
\hline Profit & $\begin{array}{r}0.0000 \\
(0.0000)\end{array}$ & $\begin{array}{r}0.0570 \\
(0.0428)\end{array}$ & $\begin{array}{r}0.0004 \\
(0.0060)\end{array}$ & $\begin{array}{r}0.4735 \\
(2.7574)\end{array}$ \\
\hline Leverage & $\begin{array}{r}0.0078 \\
(0.0146)\end{array}$ & $\begin{array}{r}0.0541 \\
(0.0533)\end{array}$ & $\begin{array}{c}0.7437 \\
(0.3018)^{*}\end{array}$ & $\begin{array}{l}4.9143 \\
(2.9807)\end{array}$ \\
\hline Tang & $\begin{array}{r}-0.0044 \\
(0.0123)\end{array}$ & $\begin{array}{l}-0.0188 \\
(0.0245)\end{array}$ & $\begin{array}{l}-0.2505 \\
(0.3372)\end{array}$ & $\begin{array}{r}-0.3626 \\
(2.6441)\end{array}$ \\
\hline Capx & $\begin{array}{l}0.0790 \\
(0.0290)^{* *}\end{array}$ & $\begin{array}{r}0.0944 \\
(0.0606)\end{array}$ & $\begin{array}{r}0.2734 \\
(0.3495)\end{array}$ & $\begin{array}{l}2.4583 \\
(2.7205)\end{array}$ \\
\hline Size & $\begin{array}{r}-0.0007 \\
(0.0012)\end{array}$ & $\begin{array}{l}-0.0004 \\
(0.0038)\end{array}$ & $\begin{array}{l}-0.0782 \\
(0.0260) * *\end{array}$ & $\begin{array}{r}-0.3741 \\
(0.2192)\end{array}$ \\
\hline Hot & $\begin{array}{r}0.0096 \\
(0.0065)\end{array}$ & $\begin{array}{r}0.0265 \\
(0.0218)\end{array}$ & $\begin{array}{r}0.0693 \\
(0.0785)\end{array}$ & $\begin{array}{r}0.8213 \\
(0.5949)\end{array}$ \\
\hline Herfindahl & $\begin{array}{r}-0.0081 \\
(0.0055)\end{array}$ & $\begin{array}{r}-0.0075 \\
(0.0168)\end{array}$ & $\begin{array}{l}-0.4098 \\
(0.1199)^{* *}\end{array}$ & $\begin{array}{r}-0.2655 \\
(0.6499)\end{array}$ \\
\hline Industry Homogeneity & $\begin{array}{r}0.0002 \\
(0.0001)\end{array}$ & $\begin{array}{r}0.0002 \\
(0.0003)\end{array}$ & $\begin{array}{c}0.0006 \\
(0.0061)\end{array}$ & $\begin{array}{r}0.0067 \\
(0.0218)\end{array}$ \\
\hline Industry Scope & $\begin{array}{l}1.4300 \\
(0.5036)^{* *}\end{array}$ & $\begin{array}{l}0.8140 \\
(0.1071)^{* *}\end{array}$ & $\begin{array}{r}5.8825 \\
(5.3515)\end{array}$ & $\begin{array}{r}6.0444 \\
(10.1585)\end{array}$ \\
\hline$A A A-10 y r$ & $\begin{array}{r}-0.0036 \\
(0.0032)\end{array}$ & $\begin{array}{r}-0.0030 \\
(0.0095)\end{array}$ & $\begin{array}{c}-0.1509 \\
(0.0612)^{*}\end{array}$ & $\begin{array}{r}-0.1541 \\
(0.4645)\end{array}$ \\
\hline Firms in Ind & $\begin{array}{r}0.0364 \\
(0.1691)\end{array}$ & $\begin{array}{c}0.4452 \\
(0.3005)\end{array}$ & $\begin{array}{r}5.8889 \\
(5.3464)\end{array}$ & $\begin{array}{r}4.9116 \\
(180.2271)\end{array}$ \\
\hline Sales Ind & $\begin{array}{r}-0.0173 \\
(0.1277)\end{array}$ & $\begin{array}{l}-1.6190 \\
(0.7659)^{*}\end{array}$ & $\begin{array}{l}-6.0995 \\
(8.1524)\end{array}$ & $\begin{array}{l}-75.0238 \\
(409.9471)\end{array}$ \\
\hline$M k t-r f$ & $\begin{array}{r}0.0102 \\
(0.0391)\end{array}$ & $\begin{array}{r}0.1533 \\
(0.1485)\end{array}$ & $\begin{array}{r}0.4586 \\
(0.6202)\end{array}$ & $\begin{array}{r}2.2313 \\
(4.6981)\end{array}$ \\
\hline Stock Vol & $\begin{array}{l}-0.0000 \\
(0.0000)\end{array}$ & $\begin{array}{r}-0.0000 \\
(0.0000)\end{array}$ & $\begin{array}{l}-0.0000 \\
(0.0000)^{* *}\end{array}$ & $\begin{array}{r}-0.0000 \\
(0.0000)\end{array}$ \\
\hline
\end{tabular}




\begin{tabular}{lcccc} 
GDP Growth & 0.0842 & 0.5166 & 1.8195 & 8.9179 \\
& $(0.0414)^{*}$ & $(0.2088)^{*}$ & $(1.1724)$ & $(8.8639)$ \\
Invest Growth & 0.0576 & 0.2463 & 1.1751 & 6.0711 \\
& $(0.0201)^{* *}$ & $(0.0941)^{*}$ & $(0.3781)^{* *}$ & $(2.9424)^{*}$ \\
Earn AR Disp & -0.2850 & -0.5793 & -7.7442 & -38.1004 \\
& $(0.1246)^{*}$ & $(0.3385)$ & $(1.9905)^{* *}$ & $(15.2363)^{*}$ \\
Analyst Disp & 0.1267 & 0.4181 & 0.1239 & 5.0167 \\
& $(0.0778)$ & $(0.2688)$ & $(1.4821)$ & $(11.3437)$ \\
Constant & 0.0270 & 0.0733 & 0.9082 & 5.9254 \\
& $(0.0131)^{*}$ & $(0.0360)^{*}$ & $(0.3354)^{* *}$ & $(12.2674)$ \\
\hline Chi $^{2} / \mathrm{R}^{2}$ & 38.29 & 31.17 & 0.57 & 0.53 \\
Observations & 972 & 972 & 972 & 972 \\
Number of I-O & 27 & 27 & 27 & 27 \\
\hline
\end{tabular}

